\title{
Activation in Persons with Mental Health Disorders: An Integrative Review
}

Alyson Keen ${ }^{1}$

Yvonne Lu ${ }^{1}$

Ukamaka Oruche ${ }^{1}$

Olena Mazurenko ${ }^{2}$

Claire Burke Draucker ${ }^{1}$

${ }^{1}$ Indiana University School of Nursing

2Indiana University Richard M. Fairbanks School of Public Health

Corresponding Author: Alyson Keen

Email: akeen2@iuhealth.org

Phone: (317) 341-3060

Acknowledgments: Authors would like to acknowledge Caitlin Pike, Indiana University Purdue University Indianapolis Research Engagement and Scholarly Services Coordinator \& Health Sciences Librarian, for her consultation with literature review database and search term selection.

Ethical Statements: Authors have no conflicts of interest to report.

This is the author's manuscript of the work published in final edited form as:

Keen, A., Lu, Y., Oruche, U. M., Mazurenko, O., \& Draucker, C. B. (2021). Activation in persons with mental health disorders: An integrative review. Journal of Psychiatric and Mental Health Nursing, 28(5), 873-899. 


\title{
Activation in Persons with Mental Health Disorders: An Integrative Review
}

\begin{abstract}
Introduction

Patient activation is understanding one's role in the healthcare process and having confidence, knowledge, and skills to self-manage one's health and healthcare. Researchers have begun to investigate patient activation in persons with mental health disorders, but no systematic reviews have been conducted to summarize and synthesize this research. For psychiatric mental health nurses and other clinicians to develop strategies to increase patient activation in this population, more information is needed about factors associated with activation and interventions that increase activation.
\end{abstract}

\section{Review Questions}

(1) What factors are associated with levels of activation in persons diagnosed with mental health disorders?

(2) What interventions have shown to be effective at increasing levels of activation in persons diagnosed with mental health disorders?

\section{Method}

A 5-stage integrative review as described by Whittemore \& Knafl.

\section{Results}

Twenty-nine articles were included in the review. Ten provided correlations between activation and other factors, and 20 examined the effects of interventions on activation. Some studies revealed significant correlations between a variety of heath and treatment-related factors, and others revealed that some interventions, most notably educational programs, were shown to increase activation.

\section{Discussion}


The findings of this comprehensive review can inform psychiatric mental health nurses and other clinicians in developing strategies to increase activation in the patients with whom they work. More research is needed to provide a deeper understanding of the role of activation in the recovery and treatment of persons with mental health disorders.

\section{Implications for Practice}

Psychiatric nurses and other clinicians should assess for patient activation and incorporate strategies to increase levels of activation in patients in their practice. Positive therapeutic relationships likely enhance activation in persons with mental health disorders.

Key Words: integrative review, patient activation, mental health disorders

\section{Relevance Statement:}

Although patient activation is essential for chronic disease self-management, little is known about activation in persons with mental health disorders. Mental health disorders are the fastest growing medical conditions throughout the world and are associated with high morbidity and mortality. While research suggests that improving activation in person with mental health disorders may aid in their treatment and recovery, this research had not been summarized and synthesized to inform clinical practice. This integrative review identifies factors associated with levels of activation and interventions that effectively increase activation. Psychiatric mental health nurses and other clinicians can leverage this information to develop strategies to increase activation in persons with mental health disorders. 


\section{Accessible Summary}

\section{What is known on the subject?}

- Evidence indicates a strong relationship between patient activation (i.e., confidence, knowledge, and skills to self-manage health) and positive health behaviors and outcomes in a variety of clinical populations.

- Because persons with mental health disorders experience significant disease burden but often underutilize mental health treatment or experience poor treatment outcomes, they would likely benefit from increases in activation.

- No systematic reviews have been conducted to summarize and synthesize research on patient activation in persons with mental health disorders.

\section{What this paper adds to existing knowledge?}

- To our knowledge, this is the first comprehensive review to identify factors associated with activation and interventions that have shown to be effective in persons with mental health disorders.

- This integrative review indicates that better health status, less depression, positive health attitudes and behaviors, and higher quality therapeutic relationships may be associated with higher levels of activation in persons with mental health disorders.

- This review also indicates that a variety of interventions, most notably educational programs, are effective in increasing levels of patient activation in persons with mental health disorders.

\section{What are the implications for practice?}

- Psychiatric mental health nurses and other clinicians should consider routine assessment of patient activation to inform individualized treatment plans for their clients.

- Clinicians should aim to form high quality therapeutic relationships with clients as a way to promote higher levels of activation. 
- Interventions that have been found to be effective in improving activation could be offered in a variety of mental health settings. 


\section{Introduction}

Promoting patient activation, a healthcare strategy aimed at leveraging patients as partners and active participants in their health care, could be an important component of treatment for persons with mental health disorders. Patient activation is defined as an understanding of one's role within the healthcare process and having the confidence, knowledge, and skill to self-manage one's health and healthcare (Hibbard, Stockard, Mahoney, \& Tusler, 2004). Persons with high levels of activation have collaborative relationships with their health care providers and are actively engaged in maintaining their health conditions (Hibbard et al., 2004). Hibbard's four stages of activation are as follows: (1) believing an active role is important, (2) having knowledge and confidence to take action, (3) taking action, and (4) staying on track in the presence of stress (Hibbard et al., 2004).

Research has revealed positive associations between patient activation and positive health behaviors and outcomes. Patients with higher levels of activation are more likely to engage in positive health behaviors (e.g., eating well, exercising regularly), seek preventive care (e.g., obtaining immunizations, having regular check-ups) (Hibbard \& Greene, 2013), report less emergency room use and fewer hospitalizations (Kinney, Lemon, Person, Pagoto, \& Saczynski, 2015), have better selfmanagement, improved functioning, and less costly healthcare use over time (Hibbard, Greene, Shi, Mittler, \& Scanlon, 2015), and experience enhanced surgical recovery (McDonall et al., 2019; Skolasky, Mackenzie, Wegener, \& Riley, 2011). In contrast, evidence indicates that persons with lower levels of activation have lower levels of knowledge related to self-management, poorer medication adherence, more health risk behaviors (e.g., smoking, using illicit drugs), more hospitalizations, and higher emergency room utilization (Hibbard et al., 2015).

Several factors have been shown to be associated with patient activation. A national survey of adults in the United States found that fewer chronic conditions, better self-rated health, higher levels of education, greater income, and certain age groups (i.e., ages 61-70) were associated with higher levels of activation (Smith et al., 2016). Additionally, a scoping review revealed that less depression, 
higher self-efficacy, better health status, and hope were associated with higher levels patient activation (Golubinski, Oppel, \& Schreyögg, 2020). Moreover, positive associations have been found between patient activation and patient perceptions of empowering or quality relationships with nurses (Jerofke, Weiss, \& Yakusheva, 2014) and physicians (Alexander, Hearld, Mittler, \& Harvey, 2012).

Several interventions have been developed to improve patient activation. In a review of evidence, Hibbard \& Greene (2013) described a variety of activation interventions used in healthcare, community, and workplace settings that result in improvements in activation. These interventions tend to focus on skill development, problem-solving, and peer support (e.g., disease self-management programs); changing the social environment (e.g., workplace information campaigns); and tailoring support to persons' level of activation (e.g., tailored coaching).

Evidence that higher levels of activation promote positive health outcomes in patients with chronic disease suggests that enhanced activation in patients with mental health disorders may aid in their treatment and recovery. Mental health disorders, a wide range of conditions that affect persons' mood, thinking and behavior (World Health Organization, n.d.), are prevalent in the United States and represent a major public health concern. In 2017, approximately 46.6 million adults, or one in five Americans, lived with a mental health disorder (National Institute of Mental Health, 2019). Mental health disorders are the fastest growing medical conditions in the United States (U.S.), with an estimated expenditure in 2013 of $\$ 201$ billion (Roehrig, 2016). Compared to the general population, persons with mental health disorders are at higher risk for developing co-morbid health concerns such as metabolic, cardiovascular, viral, and respiratory diseases (Hert et al., 2011). Worldwide, an estimated 8 million deaths (14.3\%) are attributed to mental health disorders annually (Walker, McGee, \& Druss, 2015).

Due to the high prevalence and disease burden of mental health disorders, treatment and recovery are important concerns. A large body of evidence supports the effectiveness of a number of mental health treatments including psychotherapy, medication, case management, hospitalization, 
complementary and alternative medicines, and self-help and peer support programs (Mental Health America, 2020). Yet underutilization and poor treatment outcomes are common in mental health populations. Experts estimate that less than half of persons diagnosed with a mental health disorder receive adequate treatment (National Institute of Mental Health, 2019), contributing to high rates of relapse (Dixon, Holoshitz, \& Nossel, 2016). For example, relapse estimates for patients diagnosed with schizophrenia or bipolar disease range from 70 to $95 \%$ within 1 to 5 years of completing treatment (Ayano \& Duko, 2017; Emsley, Chiliza, Asmal, \& Harvey, 2013; Price \& Marzani-Nissen, 2012).

Research suggests that persons with mental health disorders have less activation than persons with other chronic diseases and therefore enhancing their activation may improve treatment utilization and treatment outcomes (Chen, Mortensen, \& Bloodworth, 2014). In order for psychiatric mental health nurses and other clinicians to develop therapeutic strategies to enhance activation, information is needed about factors that are associated with activation in persons with mental health disorders and about interventions that have been shown to be effective in improving activation in this population. Although over the past decade researchers have begun to investigate patient activation in persons with mental health disorders, no systematic reviews have been conducted to summarize this research. Therefore, the aims of this integrative review are to (1) identify factors associated with levels of activation in persons with mental health disorders, and (2) determine what interventions have shown to be effective in increasing levels of activation in persons with mental health disorders.

\section{Methods}

An integrative review, based on procedures outlined by Whittemore and Knafl (2005), was conducted to address study aims. An integrative review is a systematic and rigorous process used to summarize research studies of diverse methodologies in order to provide a comprehensive understanding of a phenomenon of interest (Whittemore \& Knafl, 2005). This method was used for this review because it allows for inclusion of a broad range of evidence and was thus consistent with 
our goal of identifying factors associated with activation as well as identifying effective interventions. Review stages include problem identification, search of the literature, data evaluation, analysis of data, and presentation of findings (Whittemore \& Knafl, 2005). The review team was led by a doctoral candidate in nursing (AK, first author) and included three senior nurse researchers (YL, UO, CBD, second, third, and last author, respectively) and a senior public health researcher (OM, fourth author).

\section{Problem Identification}

The problem identification stage involves a clear selection of a phenomenon of interest and clarification of review purpose (Whittemore \& Knafl, 2005). As stated above, research has been conducted on factors associated with patient activation, as well as on interventions to increase activation among persons with mental health disorders, but this information has not been synthesized. Such a synthesis is needed to inform the development of therapeutic strategies to increase activation in this population.

\section{Literature Search}

The literature search included a number of strategies that ensured all relevant literature on the topic of the review was included. First, the authors determined the inclusion and exclusion criteria for determining relevant articles. Inclusion criteria included (a) peer-reviewed articles published in English between the years 2004 and 2020, (b) study samples included persons with mental health disorders, identified by formal diagnosis or self-report, and (c) indices of correlations between any measure of activation (e.g., Patient Activation Measure [PAM], Premium Abbreviated Activation Scale [PAAS]) and a measure of any other factor OR indices of the efficacy of any intervention on patient activation were provided. Articles were excluded if the study samples included persons with a range of chronic illnesses and findings related specifically to mental health disorders could not be disentangled from findings related to other illnesses. The search was limited to articles published after 2004 as that was the year that the PAM instrument was developed and research related to patient activation became prominent in health services research (Hibbard et al., 2004). Articles were 
excluded if studies included measures of concepts closely related to activation, such as patient engagement and shared decision-making, but did not include measures of patient activation.

Second, a search was conducted by the first author (AK) using the following databases: APA Psyclnfo, CINAHL, ProQuest Public Health, and PubMed. In consultation with the university's Research Engagement and Scholarly Services Coordinator, the following search terms were selected: "patient activation" AND ("mental health" OR "behavioral health" OR "anxiety" or "depression" OR "post-traumatic stress disorder" OR "bipolar disorder" OR "schizophrenia" OR "severe and persistent mental" OR "personality disorder" OR "obsessive compulsive" OR "addiction" OR "substance use" OR "substance abuse"). The search process is presented in the Preferred Reporting Items for Systematic Reviews and Data Analysis (PRISMA) diagram (Moher, Liberati, Tetzlaff, \& Altman, 2009) in Figure 1.

\section{Data Evaluation}

The authors used the Johns Hopkins Nursing Evidence-Based Practice Research Evidence Appraisal Tool to evaluate level and quality of articles in the final sample (Dang \& Dearholt, 2017). The articles were appraised so we could assess the strength of evidence available for each conclusion we make in our review rather than to eliminate articles for poor quality. The evidence of each study was categorized into Level I (randomized controlled trial or experimental study), Level II (quasi-experimental study), or Level III (nonexperimental descriptive, comparative, or correlational study) (Dang \& Dearholt, 2017). The quality of each article was determined to be high (A), good (B), or low (C) based on 15 questions. The items in the appraisal tool address specific quality criteria such as clear presentation of study purpose, current literature review, sufficient sample size, instrument reliability and validity, and discussion of limitations (Dang \& Dearholt, 2017). Each article was evaluated independently by two authors. Discrepancies were easily resolved by discussion and consensus by the authors following review of the questions on the appraisal tool. The results of the data evaluation for each article are displayed in Tables 1 and 2. 


\section{Analysis of Data}

The goal of data analysis is to synthesize evidence through a detailed summary and interpretation of the findings of the studies in the review (Whittemore \& Knafl, 2005). To conduct the analysis, information was extracted from the articles by the first author (AK) and displayed in two tables - one for each review aim. The information displayed on the tables was independently verified by at least one other author. Table 1 includes basic information extracted from articles in which correlations between measures of activation and measures of other factors were provided.

Conclusions were drawn were based on how many studies examined each factor, how many studies revealed significant correlations between activation and each factor, and the quality of the articles that yielded significant findings.

Table 2 includes information extracted from the articles of intervention studies in which at least one outcome was level of patient activation. Articles about the same or similar types of interventions were grouped together. Conclusions were drawn based on the number of studies that examined each type of intervention, how many studies revealed significant positive outcomes, and the quality of the articles. Conclusions based on both tables were proposed by the first author (AK) through regular discussions with the last author (CBD). All conclusions were then verified by the other authors (YL, UO, AM).

\section{Findings}

\section{Search Results}

The initial database search revealed 482 articles (see Figure 1). All citations were examined and 138 duplicate articles were removed. Next, the abstracts of the remaining articles were screened and 294 articles were removed. Most of the articles were removed because the study did not exclusively include persons with mental health disorders, patient activation was not measured, or no correlation indices or intervention outcomes related to activation were reported. A review of the 
remaining 50 full-text articles led to the additional removal of 21 articles for reasons similar to those stated above. The final sample included 29 articles.

\section{Associations Between Levels of Patient Activation and Other Factors}

Ten studies examined associations between activation and other factors (Table 1). The factors fell into three groups. The first group was individual-level factors, which included factors reflecting individual differences among persons (e.g., demographic characteristics, health status). The second group was community-level factors, which included factors reflecting characteristics of communities where persons reside (e.g., population demographics, available health resources). The third group is treatment relationship factors, which include factors related to the quality of interactions between patients and providers (e.g., therapeutic alliance, quality of communication). Some studies examined one type of factor whereas other studies examined two or three types of factors.

Of the ten studies, six used correlational cross-sectional designs (Chen, Mortensen, \& Bloodworth, 2014; Eliacin et al., 2018; Ivey, Shortell, Rodriguez, \& Wang, 2018; Kukla, Salyers, \& Lysaker, 2013; Pinto, Greenblatt, Williams, \& Kaplin, 2017; Sacks, Greene, Hibbard, \& Overton, 2014), one used a correlational longitudinal design (Allen et al., 2017), two were secondary analyses from randomized controlled trials that reported baseline associations between activation and other factors (Oles, Fukui, Rand, \& Salyers, 2015; Singla et al., 2020), and one was a randomized pragmatic clinical trial (Mccusker et al., 2016). Most of the participants in the studies were recruited from primary care clinics, mental health centers, and communities. Sample sizes ranged between 60 (Pinto et al., 2017) and 5,253 (Sacks et al., 2014). Activation was measured in six studies with the PAM-13 (Hibbard, Mahoney, Stockard, \& Tusler, 2005), in three studies with the PAM-Mental Health (MH) (Green et al., 2010), and in one study with the Premium Abbreviated Activation Scale (PAAS) (Kanter, Mulick, Busch, Berlin, \& Martell, 2007).

Based on the Johns Hopkins Nursing Evidence-Based Practice Research Evidence Appraisal Tool (Dang \& Dearholt, 2017), nine studies were evaluated to be a Level III as they used non- 
experimental designs. One study was evaluated as Level I because it was a randomized controlled trial that examined factors associated with activation at baseline. Six studies were rated high quality (A) and four were rated good quality (B).

The results are grouped according to the three type of factors identified above. The number of studies that examined associations between the factors and activation are first reported followed by report of the number of significant associations found.

\section{Individual-level Factors}

Demographic characteristics. Six studies examined associations between demographic characteristics and activation, but few associations were found. Studies examined associations between activation and education, gender, age, employment status, or insurance but found none (Allen et al., 2017; Chen et al., 2014; Kukla et al., 2013; Mccusker et al., 2016; Oles et al., 2015). Only two of the five studies that examined associations between race/ethnicity (Allen et al., 2017; Chen et al., 2014; Eliacin et al., 2018; Kukla et al., 2013; Oles et al., 2015) found associations, and both these studies found that White persons had higher levels of activation that Black persons (Chen et al., 2014; Eliacin et al., 2018). One study found associations between activation and residence in several U.S. Census Divisions (i.e., geographical sub-divisions used for statistical rather than governmental purposes) (see Table 1 for these associations) but did not find significant associations between activation and marital status, family size, family income, language, and location (large metro, small metro, nonmetro) (Chen et al., 2014). One study found no association between activation and housing status (i.e., homelessness) (Kukla et al., 2013).

Health-related factors. Nine studies examined associations between activation and a wide variety of health-related factors. Studies found positive associations between activation and selfreported mental health status (Allen et al., 2017; Mccusker et al., 2016); emotional, social, and physical functioning (Ivey et al., 2018); self-reported health status (Chen et al., 2014); and lower comorbidity (Mccusker et al., 2016) and negative associations between activation and number of 
disability days (Allen et al., 2017) and presence of emotional discomfort symptoms (Kukla et al., 2013). Conversely, some studies found no significant associations between activation and physical health status (Mccusker et al., 2016), presence of chronic disease (Chen et al., 2014), diagnosis (Kukla et al., 2013), and mild cognitive impairment (Mccusker et al., 2016).

The results of five studies that examined associations between psychiatric symptoms or diagnoses and activation were mixed. Most of these studies focused on depression. Studies found negative associations between activation and the presence of depression symptoms and/or depression severity (Pinto et al., 2017; Sacks et al., 2014; Singla et al., 2020), although one study found no association between activation and depressive symptoms (Mccusker et al., 2016). One study found positive associations between activation and depression remission and depression treatment response (Mccusker et al., 2016). The one study that focused on mental health more broadly found no association between activation and primary mental health diagnosis (Allen et al., 2017).

Six studies examined associations between activation and health attitudes and behaviors, and several associations were reported. In regard to health attitudes, studies found positive associations between activation and hope (Kukla et al., 2013; Oles et al., 2015) and global perceived recovery (Kukla et al., 2013). In regard to health behaviors, studies found positive associations between activation and better illness self-management (Kukla et al., 2013), more frequent exercise (Mccusker et al., 2016), transitioning to a normal body mass index, and meeting clinical recommendations for Papanicolaou (PAP) smears (Sacks et al., 2014). Yet studies found no associations between activation and smoking status/quitting smoking (Mccusker et al., 2016; Sacks et al., 2014), alcohol consumption (Mccusker et al., 2016), frequency of everyday activities (e.g., social activities, solitary activities) (Mccusker et al., 2016), medication adherence (Kukla et al., 2013), and meeting mammography guidelines (Sacks et al., 2014). 
Four studies examined associations between health service utilization and activation. One study found an association between activation and having a usual care source (e.g., physician's office, emergency department, outpatient clinic) (Chen et al., 2014). Other studies, however, did not find associations between activation and number of physician visits and nonpsychiatric specialty visits (Mccusker et al., 2016), attendance ratio in treatment and length in treatment (Allen et al., 2017), or treatment modalities (e.g., antidepressant medications, number of medications, counseling) (Mccusker et al., 2016).

\section{Community-level Factors}

One study examined the association between activation and community factors and found that higher per capita income, lower percentage of foreign-born populations, and availability of more community mental health centers were associated with activation (Chen et al., 2014).

\section{Treatment Relationship Factors}

Four studies examined the associations between activation and the nature of the treatment relationships between persons with mental health disorders and their providers. The studies found positive associations between activation and therapeutic alliance task/goal factor [i.e., extent of patient/provider agreement on tasks/goals to complete in treatment] (Allen et al., 2017), working alliance (Eliacin et al., 2018), quality of patient/provider communication, self-appraisal of communication skills with providers (Pinto et al., 2017) and therapy quality (Singla et al., 2020). The only treatment factor that was found not to be related to activation was bond factor [i.e., extent of patient/provider caring, respect, and trust within the relationship] (Allen et al., 2017).

\section{Summary}

Few strong conclusions can be drawn regarding associations between individual-level, community-level, and treatment relationship factors and activation in persons with mental health disorders. While there is a robust body of evidence linking these factors and activation in other chronic illness populations, we found only ten studies that have examined such links in persons with 
mental health disorders. While the studies reviewed were evaluated to be of high or good quality, they focused on a wide variety of factors and thus provided little evidence to firmly support associations between any one factor and patient activation. For example, with the exception of some evidence that race/ethnicity and residence in certain U.S. Census Divisions may influence activation, no evidence exists that ties any demographic factor to activation. Similarly, some evidence suggests that measures of health and well-being are tied to activation but because there was little consistency in the health indices measured (e.g., mental health status, general health status, social/emotional/physical functioning), it is difficult to draw any definitive conclusions about overall health and activation in persons with mental health disorders. Moreover, some evidence indicates that depression symptoms/severity are tied to lower activation, but more evidence is needed to draw firm conclusions about the role of depression in activation. Additionally, some health outlooks (e.g., hope, perceived recovery) and some health behaviors (e.g., self-management, frequent exercise) were tied to higher activation but only in a few studies. Only one study examined the relationship between community-level factors and activation and thus any conclusions linking the communities in which persons with mental health disorders live and activation are limited. For persons with mental health disorders receiving treatment, some evidence indicates that positive therapeutic relationships are linked to higher activation, but more information is also needed to understand this link.

\section{Patient Activation Interventions}

Twenty studies examined the effects of interventions on patient activation in persons with mental health disorders (Table 2). A number of outcome variables were targeted in the studies, but here we focus on only the outcome of activation. The interventions included the following approaches: education, case management/patient navigation, use of a web-based patient portal, coaching, selfreferral to treatment, and implementation of a patient feedback system. Of these studies, eleven were randomized controlled trials, eight used quasi-experimental designs, and one used a comparative effectiveness design. Most of the participants in the studies were recruited from outpatient community 
mental health centers, primary care clinics, medical centers, and hospital outpatient facilities. Sample sizes ranged from 17 (Bartels et al., 2013) to 1,259 (Guo et al., 2019). Eleven studies used the PAM13 (Hibbard et al., 2005) to measure activation, three used the PAM-22 (Hibbard et al., 2004), three used the PAM-MH (Green et al., 2010), and three used other measures of activation. Based on the Johns Hopkins Nursing Evidence-Based Practice Research Evidence Appraisal Tool, 12 studies were rated Level I $(n=12)$ and eight were rated Level II $(n=8)$. Fifteen studies were rated as high quality $(A)$, and five were rated as good quality (B).

The results are grouped according to the types of interventions examined in the studies. The number of studies that examined each type of intervention is first reported followed by report of the number of interventions found to have positive outcomes on activation.

\section{Educational Interventions}

Eleven of the studies examined the effects of educational interventions on patient activation. These interventions typically assisted persons to learn about their illness, ask questions of their providers, be involved in treatment decisions, and learn communication or self-management skills. Of these interventions, five were led by professionals (Alegría et al., 2014; Chiang et al., 2019; Fujita et al., 2010; Kaltman et al., 2016; Weisner et al., 2016), one was led by peers (Druss et al., 2010), and five were led by a combination of professionals and peers (Bartels et al., 2013; Goldberg et al., 2013; Lara-cabrera et al., 2016; Muralidharan et al., 2019; Turner, Realpe, Wallace, \& Kosmalaanderson, 2015). The number of sessions ranged between one (Lara-cabrera et al., 2016) and thirteen (Goldberg et al., 2013), with an average of seven sessions. Six of the studies were randomized controlled trials (Margarita Alegría et al., 2014; Chiang et al., 2019; Druss et al., 2010; Goldberg et al., 2013; Lara-cabrera et al., 2016; Muralidharan et al., 2019), and five used quasiexperimental designs (Bartels et al., 2013; Fujita et al., 2010; Kaltman et al., 2016; Turner et al., 2015; Weisner et al., 2016). Nine interventions were delivered to patients (Alegría et al., 2014; Druss et al., 2010; Fujita et al., 2010; Goldberg et al., 2013; Kaltman et al., 2016; Lara-cabrera et al., 2016; 
Muralidharan et al., 2019; Turner et al., 2015; Weisner et al., 2016) and two were delivered to patients and providers (Bartels et al., 2013; Chiang et al., 2019).

In the five studies that tested educational interventions using a quasi-experimental design, four interventions were found to be effective in improving activation pre- to post-test (Bartels et al., 2013; Fujita et al., 2010; Kaltman et al., 2016; Turner et al., 2015), whereas one study found no differences (Weisner et al., 2016). In the six studies that tested educational interventions using a randomized control design, five found the intervention group was more effective in improving activation than a treatment-as-usual (Alegría et al., 2014; Druss et al., 2010; Goldberg et al., 2013; Lara-cabrera et al., 2016) or attention control group (Muralidharan et al., 2019), and one found no difference between the intervention and control group (Chiang et al., 2019). Two studies examined if positive effects in activation were maintained post-intervention; one found that effects were maintained at four-month follow-up (Lara-cabrera et al., 2016), and one found effects were not maintained at two-month followup (Goldberg et al., 2013).

\section{Case Management/Patient Navigation Interventions}

Four studies examined the effects of case management/patient navigation interventions on patient activation (Cabassa et al., 2018; Chinman et al., 2013; Guo et al., 2019; Schuster et al., 2018). These interventions typically facilitated healthcare provider visits, health service coordination, and co-creation of care plans. The interventions were found to be effective in improving patient activation in a pre-posttest comparison (Cabassa et al., 2018) and when compared to a treatment-asusual group (Chinman et al., 2013). In a comparative effectiveness cluster-randomized study, a provider-supported group and a self-directed group both increased activation but the providersupported group increased activation more rapidly (Schuster et al., 2018). In a three-year pragmatic trial, no differences were found between an intervention and control group at years one and two follow-ups, but the intervention group was shown to be more effective in improving activation at year three (Guo et al., 2019). 


\section{Web-based Portal Interventions}

Two studies examined the effects of web-based portal interventions on patient activation (Denneson, Pisciotta, Hooker, Trevino, \& Dobscha, 2019; Kipping, Stuckey, Hernandez, Nguyen, \& Riahi, 2016). These interventions provided training for patients and access to their electronic health information. Both web-based interventions were found to be effective in improving patient activation in pre-posttest comparisons (Denneson et al., 2019; Kipping et al., 2016).

\section{Other Interventions}

Three of the studies tested interventions that differed from those discussed above. One study was a randomized pragmatic clinical trial examining the efficacy of a coaching intervention on activation (Mccusker et al., 2016). The intervention involved access to a mental health toolkit and assignment to a lay coach. The study found no difference in activation between the intervention and control groups (Mccusker et al., 2016). One study was a parallel group randomized controlled trial to evaluate the efficacy of a self-referral to inpatient treatment (SRIT) contract on patient activation (Moljord et al., 2017). The intervention was designed to improve patient access and participation in treatment through self-referral. The study compared the intervention to a treatment-as-usual group (Moljord et al., 2017) and found no differences in activation but did find the intervention was effective with participants with a patient activation score below a specific threshold (i.e., patient activation scores below 47) (Inger Elise O. Moljord et al., 2017). One study was a parallel group randomized controlled trial evaluating efficacy of implementing the Partners for Change Outcome Management System (PCOMS) on patient activation (Rise, Eriksen, Grimstad, \& Steinsbekk, 2016). The intervention collected and used patient feedback in treatment sessions, but the study found no difference between the intervention and treatment-as-usual group (Rise et al., 2016).

\section{Summary}

Evidence suggests a variety of interventions may be effective in improving activation in persons with mental health disorders. We identified 20 intervention studies of good or high quality that 
were delivered to persons with mental health disorders and that included activation as one of the outcome measures. The majority of these interventions used educational approaches and most of these interventions were found to have a positive effect on activation, although little is known about whether these effects last over time. Other studies demonstrated some positive effects on activation with other approaches, such as case management/patient navigation and the use of web-based portals, but due to the small number of studies examining each approach no strong conclusions can be made about the efficacy of these approaches on patient activation.

\section{Discussion}

Because patient activation is a key component of illness self-management and an important goal of treatment for persons with mental health disorders, it is important to determine what factors are associated with activation in this population. Although more research is needed, our review reveals that factors that may be associated with higher levels of activation in this population include better health status, lower depression, positive health attitudes and behaviors, and higher quality therapeutic relationships. These findings, although tentative, are consistent with other studies and reviews of activation in persons with mental health disorders and other health conditions. Similar to our findings, for example, the health attitude of hope was revealed to be positively associated with activation in a scoping review examining psychosocial and psychological factors in patients with chronic and other health conditions (Golubinski et al., 2020). Moreover, consistent with our findings, other studies with persons with chronic illness and mental health disorders revealed that the quality of relationships with healthcare providers (e.g., interpersonal communication quality, goal setting involvement by the patient) is positively associated with activation (Alexander et al., 2012; Allen et al., 2017; Eliacin et al., 2018). In one mixed methods study, persons with schizophrenia with high levels of activation highlighted collaborative treatment experiences with providers in their narratives (Salyers, Matthias, Sidenbender, \& Green, 2013). Other studies, however, have explored factors that did not figure prominently in our review. For example, in the mixed methods study cited above, 
patients with higher activation were more likely to acknowledge and accept their disease, while persons with lower levels of activation were less likely to perceive control over their illness (Salyers et al., 2013).

Interventions that increase activation in persons with mental health disorders could be important components of mental health treatments. Our review reveals evidence that suggests a variety of interventions, most notably educational programs, can improve activation in this population. This finding is consistent with prior systematic reviews and meta-analyses that have shown that a variety of interventions increase patient activation in a number of different chronic disease populations (Hosseinzadeh, Verma, \& Gopaldasani, 2020; Lin, Weng, Apriliyasari, Van Truong, \& Tsai, 2020).

\section{What Study Adds to Existing Reviews}

Other published reviews have synthesized research findings on factors associated with activation (Golubinski et al., 2020) and interventions used to increase activation (Hosseinzadeh et al., 2020; Lin et al., 2020), but these reviews have focused primarily on chronic disease populations. To our knowledge, our review is the first comprehensive review that examines factors associated with activation and interventions aimed at improving activation in persons with mental health disorders. By focusing specifically on this group, the conclusions can provide information that enables psychiatric mental health nurses and other clinicians to tailor programs and implement strategies to increase activation in persons with whom they work.

\section{Limitations}

Our conclusions should be considered in relationship to the limitations of the body of literature reviewed. The studies that investigated factors associated with activation covered a broad range of factors, but no one factor was examined by a sufficient number of studies to provide conclusive evidence of associations. Moreover, most of the studies used a cross-sectional design so we cannot make claims about causal relationships. For example, available evidence does not allow us to 
ascertain if depression dampens levels of activation or if lower levels of activation contribute to depression.

A number of limitations were also noted in the intervention literature. While a number of studies revealed that educational interventions increased activation, the interventions varied so widely it was impossible to compare across studies or conclude what components of the interventions resulted in change. The interventions varied on dose (e.g., 1 to 13 sessions), length of sessions (i.e., 30 minutes to 4 hours), intervention content, and interventionists (i.e., providers or peers). In addition, while most studies used some variation of the PAM (Hibbard et al., 2004) as an outcome measure, four studies used investigator-developed or other instruments to measure patient activation (Alegría et al., 2014; Chiang et al., 2019; Kipping et al., 2016; Singla et al., 2020), thus limiting comparison across studies. The instruments used in the majority of studies were self-report, which may have introduced participant bias into the findings. In addition, because many of the intervention studies included all persons with serious mental illnesses, but did not report outcomes according to diagnostic group, we were unable to ascertain which interventions were most likely to be effective with which diagnosis.

The majority of both the correlational and intervention studies included samples of persons with a variety of mental health disorders, and, with the exception of studies on depression, few studies focused on persons with a specific mental health disorder (e.g., bipolar disorder, schizophrenia). Therefore, no conclusions could be drawn about whether particular types of mental health disorders influence activation differentially. One group that was notably underrepresented in the studies were persons with substance use disorder. Only one study exclusively recruited persons with substance use disorder (Weisner et al., 2016), and two studies included persons with substance use and another mental health disorder (Alegría et al., 2014; Lara-cabrera et al., 2016).

Limitations to our review methods also restrict our conclusions. For both the correlational and intervention studies, we focused on activation but did not examine constructs that likely overlap with activation such as self-efficacy, self-management, and shared decision-making. We also did not 
examine the impact of activation on other health outcomes such as quality of life, decrease in disease burden, or treatment utilization. More work is thus needed to understand the complex role that activation plays in the treatment and recovery of persons with mental health disorders.

\section{Research Implications}

We recommend that future studies focus on common factors (e.g., depression, treatment relationships) thought to be associated with activation, use well-established and standardized selfreport measures of activation, and obtain observational measures of activation (e.g., independent ratings of activated behaviors within treatment sessions) in addition to self-report. We also recommend more longitudinal studies to allow conclusions regarding causal relationships among activation and other factors and to provide a better understanding of complex relationships among them. Research is also needed to develop a standardized intervention that can be tested in a variety of mental health groups. For example, the chronic disease self-management program (CDSMP), a widely used effective self-management workshop for persons with a variety of chronic illness, has been successfully adapted for use for persons with mental health disorders (Druss et al., 2010; Goldberg et al., 2013; Muralidharan et al., 2019). The program focuses on decision-making, problemsolving, and action planning and thus addresses key components of activation. With continued development, such standard programs for persons with mental health disorders could then be implemented and scaled-up in a wide variety of mental health settings.

\section{Clinical Implications}

Despite the limitations of the review, the findings suggest that psychiatric mental health nurses and other clinicians should consider activation as an important treatment goal. Routine assessment of persons' levels of activation using the PAM (Hibbard et al., 2004) could inform the development of individualized treatment plans. Clinicians should consider persons with mental health disorders as partners in treatment planning, encourage their active participation in their health care, and encourage self-management of their illness. The review points to therapeutic approaches that could 
improve activation in persons with mental health disorders. For example, our findings suggest that clinicians may be able to increase activation by using strategies that focus on health attitudes, beliefs, and behaviors, such as incorporating discussions of hope, perceived recovery, and self-management of illness into therapeutic work. Additionally, because treatment quality appears to affect activation, clinicians should always attend to the nature of their relationships with patients and continually aim to enhance therapeutic communication and strengthen the working alliance. Moreover, as our review provides information on a variety of interventions that have been shown to improve activation in persons with mental health disorders, psychiatric mental health nurses and other clinicians can consider providing such interventions in their practice settings and evaluating their effectiveness.

\section{Conclusion}

This is the first review we are aware of that provides a systematic synthesis of research on factors associated with patient activation in persons with mental health disorders and on interventions that target activation. Such information is important because persons with mental health disorders have high rates of morbidity and mortality, treatment underutilization, and poor outcomes and because improving activation may be one approach that could enhance their treatment and facilitate their recovery. The review points to some factors that are likely associated with activation and provides evidence that some interventions, especially educational programs, improve activation in this population. Although more research is needed to fully understand the role of activation in the treatment and recovery of persons with mental health disorders, psychiatric mental health nurses and other clinicians should assess levels of activation and use therapeutic strategies to improve patient activation in their clinical practice. 


\section{References}

Alegría, M, Polo, A., Gao, S., Santana, L., Rothstein, D., Jimenez, A., ... Normand, S. (2008).

Evaluation of a patient activation and empowerment intervention in mental health care. Medical Care, 26(3), 247-256.

Alegría, Margarita, Carson, N., Flores, M., Li, X., Shi, P., Lessios, A. S., ... Shrout, P. E. (2014).

Activation, Self-management, Engagement, and Retention in Behavioral Health Care A

Randomized Clinical Trial of the DECIDE Intervention. JAMA Psychiatry, 71(5), 557-565.

https://doi.org/10.1001/jamapsychiatry.2013.4519

Alexander, J. A., Hearld, L. R., Mittler, J. N., \& Harvey, J. (2012). Patient-physician role relationships and patient activation among individuals with chronic illness. Health Services Research, 47(3

PART 1), 1201-1223. https://doi.org/10.1111/j.1475-6773.2011.01354.x

Allen, M. L., Cook, B. L., Carson, N., Interian, A., La Roche, M., \& Alegría, M. (2017). Patient-Provider Therapeutic Alliance Contributes to Patient Activation in Community Mental Health Clinics. Administration and Policy in Mental Health and Mental Health Services Research, 44(4), 431440. https://doi.org/10.1007/s10488-015-0655-8

Ayano, G., \& Duko, B. (2017). Relapse and hospitalization in patients with schizophrenia and bipolar disorder at the St Amanuel Mental Specialized Hospital, Addis Ababa, Ethiopia: A comparative quantitative cross-sectional study. Neuropsychiatric Disease and Treatment, 13, 1527-1531. https://doi.org/10.2147/NDT.S139075

Bartels, S. J., Aschbrenner, K. A., Rolin, S. A., Hendrick, D. C., Naslund, J. A., \& Faber, M. J. (2013). Activating Older Adults With Serious Mental Illness for Collaborative Primary Care Visits. Psychiatric Rehabilitation Journal, 36(4), 278-288. https://doi.org/10.1037/prj0000024

Bieber, C., Muller, K. G., Nicolai, J., Hartmann, M., \& Eich, W. (2010). How does your doctor talk with you? Preliminary validation of a brief patient self-report questionnaire on the quality of physicianpatient interaction. Journal of Clinical Psychology in Medical Settings, 17, 125-136. 
Bullock, W. A. (2005). The Mental Health Recovery Measure. In H. S. (Eds. . In Campbell-Orde, T., Chamberlin, J. Carpenter, J., Leff (Ed.), Measuring the Promise of Recovery: A Compendium of Recovery Measures (pp. 36-41). Volume II. The Evaluation. Cambridge, MA: Center@HSRI.

Cabassa, L., Manrique, Y., Meyreles, Q., Camacho, D., Capitelli, L., Younge, R., ... LewisFernández, R. (2018). Bridges to Better Health and Wellness : An Adapted Health Care Manager Intervention for Hispanics with Serious Mental Illness. Administration and Policy in Mental Health and Mental Health Services Research, 45(1), 163-173. https://doi.org/10.1007/s10488-016$0781-y$

Cegala, D. J., Coleman, M. T., \& Turner, J. W. (1998). The development and partial assessment of the medical communication competence scale. Health Communication, 10(3), 261-288.

Cella, D., Riley, W., Stone, A., Rothrock, N., Reeve, B., Yount, S., ... PROMIS Cooperative Group. (2010). The Patient-Reported Outcomes Measurement Information System (PROMIS) developed and tested its first wave of adult self-reported health outcome item banks: 2005-2008. Journal of Clinical Epidemiology, 63(11), 1179-1194.

Chen, J., Mortensen, K., \& Bloodworth, R. (2014). Exploring Contextual Factors and Patient Activation : Evidence From a Nationally Representative Sample of Patients With Depression. https://doi.org/10.1177/1090198114531781

Chiang, M., Chang, J., Nakash, O., Cruz-Gonzalez, M., Fillbrunn, M. K., \& Alegría, M. (2019). Change in patient activation and mental illness symptoms after communication training: A multisite study with a diverse patient sample. Psychiatric Services, 70(8), 696-702. https://doi.org/10.1176/appi.ps.201800216

Chinman, M., Oberman, R. S., Hanusa, B. H., Cohen, A. N., Salyers, M. P., Twamley, E. W., \& Young, A. S. (2013). A Cluster Randomized Trial of Adding Peer Specialists to Intensive Case Management Teams in the Veterans Health Administration. Journal of Behavioral Health Services \& Research, 42(1), 109-122. https://doi.org/10.1007/s11414-013-9343-1 
Corrigan, P., Faber, D., Rashid, F., \& Leary, M. (1999). The construct validity of empowerment among consumers of mental health services. Schizophrenia Research, 38, 77-84.

Dang, D., \& Dearholt, S. (2017). Johns Hopkins nursing evidence-based practice: model and guidelines (3rd ed.). Sigma Theta Tau International; Indianapolis, IN.

Denneson, L. M., Pisciotta, M., Hooker, E. R., Trevino, A., \& Dobscha, S. K. (2019). Impacts of a web-based educational program for veterans who read their mental health notes online. Journal of the American Medical Informatics Association, 26(1), 3-8. https://doi.org/10.1093/jamia/ocy134

Dixon, L. B., Holoshitz, Y., \& Nossel, I. (2016). Treatment engagement of individuals experiencing mental illness: Review and update. World Psychiatry, 15(1), 13-20. https://doi.org/10.1002/wps.20306

Druss, B. G., Zhao, L., Esenwein, S. A. Von, Bona, J. R., Fricks, L., Jenkins-tucker, S., ... Lorig, K. (2010). The Health and Recovery Peer ( HARP ) Program : A peer-led intervention to improve medical self-management for persons with serious mental illness. Schizophrenia Research, 118(1-3), 264-270. https://doi.org/10.1016/j.schres.2010.01.026

Eliacin, J., Coffing, J. M., Matthias, M. S., Burgess, D. J., Bair, M. J., \& Rollins, A. L. (2018). The Relationship Between Race, Patient Activation, and Working Alliance: Implications for Patient Engagement in Mental Health Care. Administration and Policy in Mental Health and Mental Health Services Research, 45(1), 186-192. https://doi.org/10.1007/s10488-016-0779-5

Emsley, R., Chiliza, B., Asmal, L., \& Harvey, B. H. (2013). The nature of relapse in schizophrenia. BMC Psychiatry, 13(1), 1. https://doi.org/10.1186/1471-244X-13-50

Fujita, E., Kato, D., Suzuki, Y., Uchiyama, S., Watanabe, A., Uehara, K., ... Hirayasu, Y. (2010). Implementing the Illness Management and Recovery Program in Japan. Psychiatric Services, 61(11), 7-11.

Goldberg, R., Dickerson, F., Lucksted, A., Brown, C., Weber, E., Tenhula, W., ... Dixon, L. (2013). 
Living Well : An Intervention to Improve Self-Management of Medical Illness for Individuals With Serious Mental IIIness. Psychiatric Services, 64(1), 51-57.

https://doi.org/10.1176/appi.ps.201200034

Golubinski, V., Oppel, E. M., \& Schreyögg, J. (2020). A systematic scoping review of psychosocial and psychological factors associated with patient activation. Patient Education and Counseling, In Press. https://doi.org/10.1016/j.pec.2020.05.005

Green, C., Perrin, N., Polen, M., Leo, M., Hibbard, J., \& Tusler, M. (2010). Development of the Patient Activation Measure for mental health. Administration and Policy in Mental Health, (37), 327-333.

Guo, Y., Vogel, W. B., Muller, K. E., Stoner, D., Huo, T., \& Shenkman, E. A. (2019). The Wellness Incentive and Navigation intervention improved health-related quality of life among Medicaid enrollees: A randomized pragmatic clinical trial. Health Services Research, 54(6), 1156-1165. https://doi.org/10.1111/1475-6773.13235

Hert, M., Correll, C. U., Bobes, J., Cetkovich-Bakmas, M., Cohen, D. A. N., Asai, I., ... Leucht, S. (2011). Physical illness in patients with severe mental disorders. I. Prevalence, impact of medications and disparities in health care. World Psychiatry, 10(1), 52-77. https://doi.org/10.1002/j.2051-5545.2011.tb00014.x

Hibbard, J. H., \& Greene, J. (2013). What the evidence shows about patient activation: Better health outcomes and care experiences; fewer data on costs. Health Affairs, 32(2), 207-214. https://doi.org/10.1377/hlthaff.2012.1061

Hibbard, J. H., Greene, J., Shi, Y., Mittler, J., \& Scanlon, D. (2015). Taking the Long View: How Well Do Patient Activation Scores Predict Outcomes Four Years Later? Medical Care Research and Review, 72(3), 324-337. https://doi.org/10.1177/1077558715573871

Hibbard, J. H., Mahoney, E. R., Stockard, J., \& Tusler, M. (2005). Development and testing of a short form of the patient activation measure. Health Services Research, 40(6 I), 1918-1930. https://doi.org/10.1111/j.1475-6773.2005.00438.x 
Hibbard, J. H., Stockard, J., Mahoney, E. R., \& Tusler, M. (2004). Development of the Patient Activation Measure (PAM): Conceptualizing and Measuring Activation in Patients and Consumers. Health Services Research, 39(4p1), 1005-1026. https://doi.org/10.1111/j.1475$6773.2004 .00269 . x$

Hosseinzadeh, H., Verma, I., \& Gopaldasani, V. (2020). Patient activation and Type 2 diabetes mellitus self-management: A systematic review and meta-Analysis. Australian Journal of Primary Health, 26(6), 431-442. https://doi.org/10.1071/PY19204

Ivey, S. L., Shortell, S. M., Rodriguez, H. P., \& Wang, Y. (2018). Patient Engagement in ACO Practices and Patient-reported Outcomes among Adults with Co-occurring Chronic Disease and Mental Health Conditions. Medical Care, 56(7), 551-556.

https://doi.org/10.1097/MLR.0000000000000927

Jerofke, T., Weiss, M., \& Yakusheva, O. (2014). Patient perceptions of patient-empowering nurse behaviours, patient activation and functional health status in postsurgical patients with lifethreatening long-term illnesses. Journal of Advanced Nursing, 70(6), 1310-1322. https://doi.org/10.1111/jan.12286

Kaltman, S., Serrano, A., Talisman, N., Magee, M. F., Cabassa, L. J., Pulgar-Vidal, O., \& Peraza, D. (2016). Type 2 Diabetes and Depression: A Pilot Trial of an Integrated Self-management Intervention for Latino Immigrants. The Diabetes Educator, 42(1), 87-95. https://doi.org/10.1177/0145721715617536

Kanter, J., Mulick, P., Busch, A., Berlin, K., \& Martell, C. (2007). The Behavioral Activation for Depression Scale (BADS): psychometric properties and factor structure. Journal of Psychopathology and Behavioral Assessment, 29, 191-202.

Kay S, Fiszbein A, O. L. (1987). The Positive and Negative Syndrome Scale (PANSS) for schizophrenia. Schizophrenia Bulletin, 13, 261-276.

Kim, S. C., Boren, D., \& Solem, S. L. (2001). The kim alliance scale: Development and preliminary 
testing. Clinical Nursing Research, 10(3), 314-331.

Kinney, R. L., Lemon, S. C., Person, S. D., Pagoto, S. L., \& Saczynski, J. S. (2015). The association between patient activation and medication adherence, hospitalization, and emergency room utilization in patients with chronic illnesses: A systematic review. Patient Education and Counseling, 98(5), 545-552. https://doi.org/10.1016/j.pec.2015.02.005

Kipping, S., Stuckey, M. I., Hernandez, A., Nguyen, T., \& Riahi, S. (2016). A web-based patient portal for mental health care: Benefits evaluation. Journal of Medical Internet Research, 18(11), 1-9. https://doi.org/10.2196/jmir.6483

Kroenke, K., Spitzer, R. L., \& Williams, J. B. (2001). The PHQ-9: validity of a brief depression severity measure. Journal of General Internal Medicine, 16, 606-613.

Kroenke, K., Spitzer, R., Williams, J., \& Lowe, B. (2009). An ultra-brief screening scale for anxiety and depression: the PHQ-4. Psychosomatics, 50(6), 613-621.

Kukla, M., Salyers, M., \& Lysaker, P. (2013). Levels of Patient Activation Among Adults With Schizophrenia: Associations with Hope, Symptoms, Medication Adherance, and Recovery Attitidues. J Nerv Ment Dis, 201(4), 339-344. https://doi.org/10.1097/NMD.0b013e318288e253

Lara-cabrera, M. L., Salvesen, Ø., Berg, M., De, C., Cabral, V., \& Gråwe, R. W. (2016). Patient Education and Counseling The effect of a brief educational programme added to mental health treatment to improve patient activation : A randomized controlled trial in community mental health centres. Patient Education and Counseling, 99(5), 760-768.

https://doi.org/10.1016/j.pec.2015.11.028

Lin, M. Y., Weng, W. S., Apriliyasari, R. W., Van Truong, P., \& Tsai, P. S. (2020). Effects of patient activation intervention on chronic diseases: A meta-analysis. Journal of Nursing Research, 28(5), 1-16. https://doi.org/10.1097/jnr.0000000000000387

Mccusker, J., Lambert, S. D., Cole, M. G., Ciampi, A., Strumpf, E., Freeman, E. E., \& Belzile, E. (2016). Activation and Self-Efficacy in a Randomized Trial of a Depression Self-Care 
Intervention. Health Education \& Behavior, 43(6), 716-725.

https://doi.org/10.1177/1090198116637601

McDonall, J., De Steiger, R., Reynolds, J., Redley, B., Livingston, P. M., Hutchinson, A. F., \& Botti, M. (2019). Patient activation intervention to facilitate participation in recovery after total knee replacement (MIME): A cluster randomised cross-over trial. BMJ Quality and Safety, 28(10), 782-792. https://doi.org/10.1136/bmjqs-2018-008975

Mental Health America. (2020). Mental Health Treatments. Retrieved September 6, 2020, from https://www.mhanational.org/mental-health-treatments

Moher, D., Liberati, A., Tetzlaff, J., \& Altman, D. G. (2009). Preferred reporting items for systematic reviews and meta-analyses : the PRISMA statement. British Medical Journal, 2535, 1-8. https://doi.org/10.1136/bmj.b2535

Moljord, I. E.O., Lara-Cabrera, M. L., Salvesen, Rise, M. B., Bjørgen, D., Antonsen, D., ... Eriksen, L. (2017). Twelve months effect of self-referral to inpatient treatment on patient activation, recovery, symptoms and functioning: A randomized controlled study. Patient Education and Counseling, 100(6), 1144-1152. https://doi.org/10.1016/j.pec.2017.01.008

Moljord, Inger Elise O., Lara-Cabrera, M. L., Perestelo-Pérez, L., Rivero-Santana, A., Eriksen, L., \& Linaker, O. M. (2015). Psychometric properties of the Patient Activation Measure-13 among outpatients waiting for mental health treatment: A validation study in Norway. Patient Education and Counseling, 98(11), 1410-1417. https://doi.org/10.1016/j.pec.2015.06.009

Morisky D, Green L, L. D. (1986). Concurrent and predictive validity of a self-reported measure of medication adherence. Medical Care, 24, 67-74.

Mueser, K., Gingerich, S., Salyers, M., McGuire, A., Reyes, R., \& Cunningham, H. (2004). The IIIness Management and Recovery (IMR) Scale. Concord, New Hampshire: Dartmouth Psychiatric Research.

Muralidharan, A., Brown, C. H., Peer, J. E., Klingaman, E. A., Hack, S. M., Li, L., .. Goldberg, R. W. 
(2019). Living well: An intervention to improve medical illness self-management among individuals with serious mental illness. Psychiatric Services, 70(1), 19-25.

https://doi.org/10.1176/appi.ps.201800162

National Institute of Mental Health. (2019). Mental IIIness. Retrieved August 22, 2020, from https://www.nimh.nih.gov/health/statistics/mental-illness.shtml

Oles, S. K., Fukui, S., Rand, K. L., \& Salyers, M. P. (2015). The relationship between hope and patient activation in consumers with schizophrenia : Results from longitudinal analyses. Psychiatry Research, 228, 272-276. https://doi.org/10.1016/j.psychres.2015.05.100

Pinto, M. D., Greenblatt, A. M., Williams, B. L., \& Kaplin, A. I. (2017). Exploring the Mechanism of the Clinical Encounter on Depressive Symptoms in Young Adults: A Path Analysis. Issues in Mental Health Nursing, 38(7), 533-539. https://doi.org/10.1080/01612840.2017.1305023

Price, A. L., \& Marzani-Nissen, G. R. (2012). Bipolar disorders: A review. American Family Physician, 85(5), 483-493.

Rise, M. B., Eriksen, L., Grimstad, H., \& Steinsbekk, A. (2016). The long-term effect on mental health symptoms and patient activation of using patient feedback scales in mental health out-patient treatment. A randomised controlled trial. Patient Education and Counseling, 99, 164-168. https://doi.org/10.1016/j.pec.2015.07.016

Roehrig, C. (2016). Mental disorders top the list of the most costly conditions in the United States: \$201 Billion. Health Affairs, 35(6), 1130-1135. https://doi.org/10.1377/hlthaff.2015.1659

Sacks, R. M., Greene, J., Hibbard, J. H., \& Overton, V. (2014). How well do patient activation scores predict depression outcomes one year later? Journal of Affective Disorders, 169, 1-6. https://doi.org/10.1016/j.jad.2014.07.030

Salyers, M. P., Matthias, M. S., Sidenbender, S., \& Green, A. (2013). Patient Activation in Schizophrenia : Insights from Stories of IIIness and Recovery. Adm Policy Ment Health, 40, 419427. https://doi.org/10.1007/s10488-012-0435-7 
Schuster, J., Nikolajski, C., Kogan, J., Kang, C., Schake, P., Carney, T., ... Reynolds, C. F. (2018). A payer-guided approach to widespread diffusion of behavioral health homes in real-world settings. Health Affairs, 37(2), 248-256. https://doi.org/10.1377/hlthaff.2017.1115

Singla, D. R., Hollon, S. D., Velleman, R., Weobong, B., Nadkarni, A., Fairburn, C. G., ... Patel, V. (2020). Temporal pathways of change in two randomized controlled trials for depression and harmful drinking in Goa, India. Psychological Medicine, 50(1), 68-76.

https://doi.org/10.1017/S0033291718003963

Singla, D. R., Weobong, B., Nadkarni, A., Chowdhary, N., Shinde, S., Anand, A., ... Patel, V. (2014). Improving the scalability of psychological treatments in developing countries: An evaluation of peer-led therapy quality assessment in Goa, India. Behaviour Research and Therapy, 60, 53-59. https://doi.org/10.1016/j.brat.2014.06.006

Skolasky, R. L., Mackenzie, E. J., Wegener, S. T., \& Riley, L. H. (2011). Patient activation and functional recovery in persons undergoing spine surgery. Orthopedics, 34(11), 888.

Smith, S. G., Pandit, A., Rush, S. R., Wolf, M. S., Carol, J., Smith, S. G., ... Simon, C. J. (2016). The Role of Patient Activation in Preferences for Shared Decision Making: Results From a National Survey of U . S . Adults The Role of Patient Activation in Preferences for Shared Decision Making: Results From a National Survey of U . S . Adults. UHCM, 21(1), 67-75. https://doi.org/10.1080/10810730.2015.1033115

Snyder, C., Sympson, S., Ybasco, F., Borders, T., Babyak, M., \& Higgins, R. (1996). Development and validation of the State Hope Scale. Journal of Personality and Social Psychology, 70, 321335.

Tracey, T. J., \& Kokotovic, A. M. (1989). Factor structure of the working alliance inventory. Psychological Assessment, 1, 207-210.

Turner, A., Realpe, A. X., Wallace, L. M., \& Kosmala-anderson, J. (2015). A co-produced selfmanagement programme improves psychosocial outcomes for people living with depression. 
Mental Health Review Journal, 20(4), 242-255. https://doi.org/10.1108/MHRJ-05-2014-0017

Walker, E., McGee, R., \& Druss, B. (2015). Mortality in Mental Disorders and Global Disease Burden Implications: A Systematic Reivew and Meta-analysis. JAMA Psychiatry, 72(4), 334-341. https://doi.org/doi:10.1001/jamapsychiatry.2014.2502

Ware, J. E., Kosinski, M., \& Keller, S. D. (1996). A 12-item short form health survey: Construction of scales and preliminary tests of reliability and validity. Medical Care, 34, 220-233.

Weisner, C. M., Chi, F. W., Lu, Y., Ross, T. B., Wood, S. B., Hinman, A., ... Sterling, S. A. (2016).

Examination of the Effects of an Intervention Aiming to Link Patients Receiving Addiction Treatment With Health Care The LINKAGE Clinical Trial. JAMA Psychiatry, 73(8), 804-814. https://doi.org/10.1001/jamapsychiatry.2016.0970

Whittemore, R., \& Knafl, K. (2005). The integrative review: updated methodology. Journal of Advanced Nursing, 52(5), 546-553. https://doi.org/10.1111/j.1365-2648.2005.03621.x World Health Organization. (n.d.). Mental Disorders. Retrieved August 26, 2020, from https://www.who.int/mental_health/management/en/ Zigmond, A. S., \& Snaith, R. P. (1983). The hospital anxiety and depression scale. Acta Psychiatrica Scandinavica, 67(6), 361-370. 
Table 1: Individual-level, community-level, and treatment relationship factors

\begin{tabular}{|c|c|c|c|c|c|c|c|}
\hline $\begin{array}{l}\text { Author } \\
\text { (year) }\end{array}$ & Design & Purpose & $\begin{array}{l}\text { Sample/ } \\
\text { Setting }\end{array}$ & $\begin{array}{l}\text { Activation } \\
\text { Variable } \\
\text { (Measure) }\end{array}$ & Other Variables & $\begin{array}{l}\text { Associations between PAM and other } \\
\text { variables }\end{array}$ & $\begin{array}{l}\text { Evidence } \\
\text { Level, } \\
\text { Quality } \\
\end{array}$ \\
\hline $\begin{array}{l}\text { Allen et al. } \\
(2017)\end{array}$ & $\begin{array}{l}\text { Correlational, } \\
\text { longitudinal }\end{array}$ & $\begin{array}{l}\text { "To estimate the } \\
\text { unique effects of } \\
\text { communication } \\
\text { and therapeutic } \\
\text { alliance on } \\
\text { patient } \\
\text { activation both } \\
\text { cross sectionally } \\
\text { and } \\
\text { longitudinally in } \\
\text { patients } \\
\text { attending } \\
\text { community- } \\
\text { based mental } \\
\text { health clinics" } \\
\text { (p. } 432 \text { ) }\end{array}$ & $\begin{array}{l}\text { Patients from } \\
13 \text { community- } \\
\text { based mental } \\
\text { health clinics } \\
\text { in the United } \\
\text { States (U.S.) } \\
(\mathrm{N}=264)\end{array}$ & $\begin{array}{l}\text { Patient activation } \\
\text { (Patient Activation } \\
\text { Measure-13 } \\
\text { [PAM-13]) } \\
\text { (Hibbard et al., } \\
\text { 2005) }\end{array}$ & $\begin{array}{l}\text { Therapeutic alliance } \\
\text { (Working Alliance } \\
\text { Inventory-Short [WAI-SR], } \\
\text { (task/goal and bond } \\
\text { factors) (Tracey \& } \\
\text { Kokotovic, 1989) } \\
\text { Communication (Kim } \\
\text { Alliance Scale) (Kim, } \\
\text { Boren, \& Solem, 2001) } \\
\text { Clinical characteristics } \\
\text { (self-reported mental } \\
\text { health status, primary } \\
\text { mental health diagnosis, } \\
\text { disability days, attendance } \\
\text { ratio, self-reported length } \\
\text { in treatment) } \\
\text { Socio-demographic } \\
\text { characteristics (gender, } \\
\text { race/ethnicity, age, } \\
\text { immigrant, education, } \\
\text { employment status, } \\
\text { insurance status) }\end{array}$ & 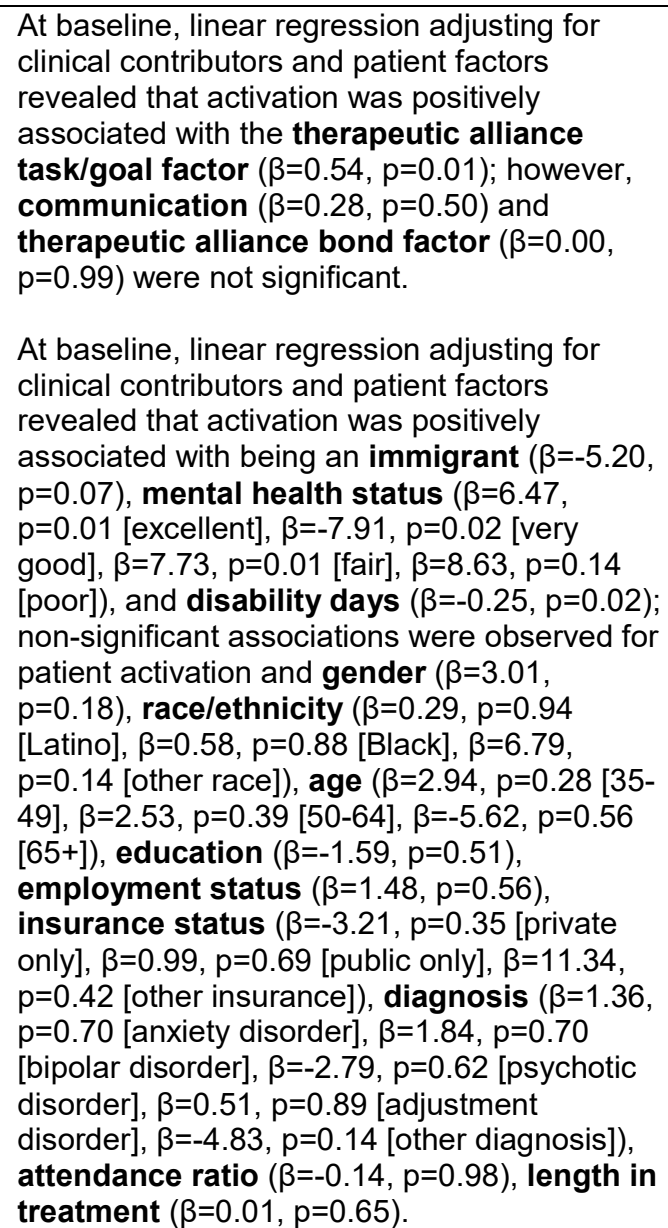 & III, A \\
\hline $\begin{array}{l}\text { Chen et al. } \\
(2014)\end{array}$ & $\begin{array}{l}\text { Correlational, } \\
\text { cross- } \\
\text { sectional }\end{array}$ & $\begin{array}{l}\text { "Examine the } \\
\text { association } \\
\text { between } \\
\text { contextual } \\
\text { factors and self- } \\
\text { reported } \\
\text { activation levels } \\
\text { among patients } \\
\text { with depression" } \\
\text { (p.614) }\end{array}$ & $\begin{array}{l}\text { Data from the } \\
\text { Health } \\
\text { Tracking } \\
\text { Household } \\
\text { Survey } 2007 \\
\text { and Area } \\
\text { Health } \\
\text { Resource File } \\
2008 \text { for } \\
\text { people with }\end{array}$ & $\begin{array}{l}\text { Patient activation } \\
\text { (PAM-13) } \\
\text { (Hibbard et al., } \\
\text { 2005) }\end{array}$ & $\begin{array}{l}\text { Usual source of care } \\
\text { (yes/no) } \\
\text { Care source (physician } \\
\text { office, emergency } \\
\text { department, hospital } \\
\text { outpatient clinic or health } \\
\text { center, other care source) }\end{array}$ & $\begin{array}{l}\text { In multivariate linear regression controlling for } \\
\text { site of care, patients utilizing hospital } \\
\text { outpatient clinics (coef }-3.59, p<0.05 \text { ) or } \\
\text { emergency department (coef }-5.04, p<0.05 \text { ) } \\
\text { had lower activation index than those using } \\
\text { physician's offices as usual care source. } \\
\text { In a multivariate linear regression controlling } \\
\text { for community characteristics, higher } \\
\text { activation was associated with higher per }\end{array}$ & III, A \\
\hline
\end{tabular}




\begin{tabular}{|c|c|c|c|c|c|c|c|}
\hline & & & $\begin{array}{l}\text { diagnosed } \\
\text { depression in } \\
\text { U.S. }(N=1670)\end{array}$ & & $\begin{array}{l}\text { Community characteristics } \\
\text { (number of mental health } \\
\text { institutions, number of } \\
\text { psychiatrists for every } \\
1,000 \text { citizens, percentage } \\
\text { of foreign-born citizens, } \\
\text { percentage of non-White } \\
\text { citizens, college or higher } \\
\text { education level, per capita } \\
\text { income) } \\
\text { Population characteristics } \\
\text { (age, sex, race/ethnicity, } \\
\text { marital status, family size, } \\
\text { education, income, } \\
\text { location) }\end{array}$ & 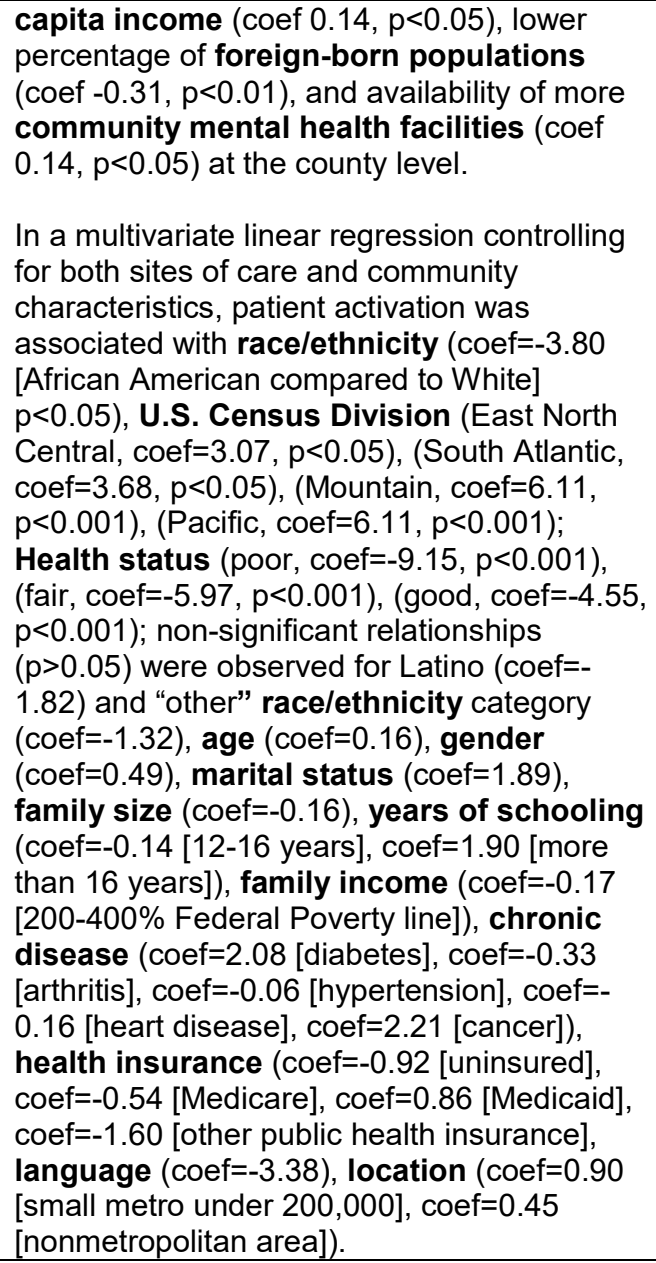 & \\
\hline $\begin{array}{l}\text { Eliacin et } \\
\text { al. (2018) }\end{array}$ & $\begin{array}{l}\text { Correlational, } \\
\text { cross- } \\
\text { sectional }\end{array}$ & $\begin{array}{l}\text { "To examine the } \\
\text { association } \\
\text { between } \\
\text { race and two } \\
\text { key aspects of } \\
\text { patient } \\
\text { engagement: } \\
\text { patient } \\
\text { activation and } \\
\text { working } \\
\text { alliance" (p. } \\
\text { 187) }\end{array}$ & $\begin{array}{l}\text { African- } \\
\text { American (AA) } \\
\text { and White } \\
\text { veterans from } \\
\text { outpatient } \\
\text { mental health } \\
\text { clinics in } \\
\text { Indiana } \\
(\mathrm{N}=152)\end{array}$ & $\begin{array}{l}\text { Patient activation } \\
\text { (PAM-MH) (Green } \\
\text { et al., 2010) }\end{array}$ & $\begin{array}{l}\text { Working alliance (WAI- } \\
\text { SR), (Tracey \& Kokotovic, } \\
\text { 1989) } \\
\text { Race (AA or White); } \\
\text { gender; age; education; } \\
\text { employment; length of } \\
\text { time with employer (self- } \\
\text { report and medical } \\
\text { records) }\end{array}$ & $\begin{array}{l}\text { In stepwise regression analysis, significant } \\
\text { association between race and activation was } \\
\text { identified }(\mathrm{p}=0.002) \text {. White veterans } \\
(\mathrm{M}=65.3+/-15.5) \text { had significantly higher } \\
\text { activation scores than African American } \\
\text { veterans }(\mathrm{M}=56.6+/-14.7) \text {. } \\
\text { In linear regression, after controlling for } \\
\text { demographics, working alliance predicted } \\
\text { activation }(\mathrm{R} 2=0.297, \mathrm{~F}(7,100)=6.044, \mathrm{p}< \\
0.001) \text {. }\end{array}$ & III, B \\
\hline
\end{tabular}




\begin{tabular}{|c|c|c|c|c|c|c|c|}
\hline $\begin{array}{l}\text { Ivey et al. } \\
(2018)\end{array}$ & $\begin{array}{l}\text { Correlational, } \\
\text { cross- } \\
\text { sectional }\end{array}$ & $\begin{array}{l}\text { "To assess the } \\
\text { extent to which } \\
\text { practices with } \\
\text { patient-centered } \\
\text { cultures, greater } \\
\text { shared decision- } \\
\text { making } \\
\text { strategies, and } \\
\text { better } \\
\text { coordination } \\
\text { among team } \\
\text { members have } \\
\text { better patient- } \\
\text { reported } \\
\text { outcomes } \\
\text { (PROs) for } \\
\text { patients with } \\
\text { diabetes and/or } \\
\text { cardiovascular } \\
\text { and comorbid } \\
\text { mental health } \\
\text { diagnoses" (p. } \\
551 \text { ) }\end{array}$ & $\begin{array}{l}\text { Patients with } \\
\text { cardiovascular, } \\
\text { diabetes and } \\
\text { coexisting } \\
\text { mental health } \\
\text { diagnosis from } \\
\text { participating } \\
\text { primary care } \\
\text { practices } \\
(\mathrm{N}=606)\end{array}$ & $\begin{array}{l}\text { Patient activation } \\
\text { (PAM-13) } \\
\text { (Hibbard et al., } \\
\text { 2005) }\end{array}$ & $\begin{array}{l}\text { Emotional functioning } \\
\text { (Patient Health } \\
\text { Questionnaire } 4 \text { [PHQ-4]) } \\
\text { (Kroenke, Spitzer, } \\
\text { Williams, \& Lowe, 2009) } \\
\text { Physical functioning (12- } \\
\text { items from Patient- } \\
\text { Reported Outcomes } \\
\text { Measurement System } \\
\text { [PROMIS]) (Cella et al., } \\
\text { 2010) } \\
\text { Social functioning (8-items } \\
\text { from PROMIS) (Cella et } \\
\text { al., 2010) }\end{array}$ & $\begin{array}{l}\text { In hierarchical linear regression, } \\
\text { patient activation was positively associated } \\
\text { with social }(\beta=0.62, P \leq 0.001) \text {, emotional } \\
(\beta=0.33, P \leq 0.001) \text {, and physical functioning } \\
(\beta=0.42, P \leq 0.001) \text {. }\end{array}$ & III, B \\
\hline $\begin{array}{l}\text { Kukla et } \\
\text { al. (2013) }\end{array}$ & $\begin{array}{l}\text { Correlational, } \\
\text { cross- } \\
\text { sectional }\end{array}$ & $\begin{array}{l}\text { "To understand } \\
\text { the relationship } \\
\text { between patient } \\
\text { activation and } \\
\text { symptoms, } \\
\text { medication } \\
\text { adherence, } \\
\text { recovery } \\
\text { attitudes, and } \\
\text { hope (p.339)" }\end{array}$ & $\begin{array}{l}\text { Patients with } \\
\text { schizophrenia } \\
\text { at a } \\
\text { community } \\
\text { mental health } \\
\text { center in } \\
\text { Indiana } \\
(\mathrm{N}=119)\end{array}$ & $\begin{array}{l}\text { Patient activation } \\
\text { (Patient Activation } \\
\text { Measure-Mental } \\
\text { Health [PAM-MH]) } \\
\text { (Green et al., } \\
\text { 2010) }\end{array}$ & $\begin{array}{l}\text { Demographic } \\
\text { characteristics (sex, } \\
\text { ethnicity, diagnosis, } \\
\text { education, housing, } \\
\text { employment status) } \\
\text { Psychiatric symptoms } \\
\text { (Positive and Negative } \\
\text { Syndrome Scale [PANSS]) } \\
\text { (Kay \& Fiszbein, 1987) } \\
\text { Medication adherence } \\
\text { (Morisky Medication } \\
\text { Adherence Scale [MMAS]) } \\
\text { (Morisky \& Green, 1986) } \\
\text { Global perceived recovery } \\
\text { (Recovery Assessment } \\
\text { Scale [RAS]) (Corrigan, } \\
\text { Faber, Rashid, \& Leary, } \\
\text { 1999) } \\
\text { Hope (Adult State Hope } \\
\text { Scale[AHS]) (Snyder et } \\
\text { al., 1996) }\end{array}$ & $\begin{array}{l}\text { Bivariate correlations revealed that patient } \\
\text { activation was positively correlated with global } \\
\text { perceived recovery }(r=0.66, p<0.01) \text {, hope } \\
(r=0.57, p<0.01), \text { and illness self- } \\
\text { management }(r=0.42, p<0.01) \text { and patient } \\
\text { activation was negatively correlated with } \\
\text { emotional discomfort symptoms (PANSS) } \\
(r=-0.28, p<0.01) \text {; patient activation was not } \\
\text { significantly related to medication adherence } \\
\text { (coef=-0.18, } p<0.01) \text {. } \\
\text { In stepwise regression, hope (R2=0.49, } \\
F[2,105]=50.1, p<0.01) \text { and global perceived } \\
\text { recovery }(R 2=0.44, F[1,106]=83.6, p<0.01) \\
\text { predicted patient activation. } \\
\text { Patient activation was not significantly } \\
\text { associated with sex, race/ethnicity, } \\
\text { diagnosis, education, housing, or } \\
\text { employment status }(p=>0.01)^{\dagger} \text {. }\end{array}$ & III, B \\
\hline
\end{tabular}




\begin{tabular}{|c|c|c|c|c|c|c|c|}
\hline & & & & & $\begin{array}{l}\text { Global illness self- } \\
\text { management (IIIness } \\
\text { Management and } \\
\text { Recovery scale [IMR]) } \\
\text { (Mueser et al., 2004) }\end{array}$ & & \\
\hline $\begin{array}{l}\text { McCusker } \\
\text { et al. } \\
(2016)\end{array}$ & $\begin{array}{l}\text { Randomized } \\
\text { pragmatic } \\
\text { clinical trial§ }\end{array}$ & $\begin{array}{l}\text { "To describe the } \\
\text { cross-sectional } \\
\text { and longitudinal } \\
\text { associations of } \\
\text { activation and } \\
\text { self-efficacy with } \\
\text { demographic, } \\
\text { physical and } \\
\text { mental health } \\
\text { status, health } \\
\text { behaviors, } \\
\text { depression self- } \\
\text { care, health } \\
\text { care utilization, } \\
\text { and use of self- } \\
\text { care tools; and } \\
\text { to examine the } \\
\text { effects of a } \\
\text { depression self- } \\
\text { care coaching } \\
\text { intervention on } \\
\text { these two } \\
\text { outcomes" } \\
\text { (p.716) }\end{array}$ & $\begin{array}{l}\text { Patients from } \\
41 \text { family } \\
\text { doctors in } \\
\text { Montreal with } \\
\text { at least one } \\
\text { chronic } \\
\text { condition or } \\
\text { chronic pain } \\
\text { and minimum } \\
\text { of mild } \\
\text { depression } \\
(\mathrm{N}=215)\end{array}$ & $\begin{array}{l}\text { Patient activation } \\
\text { (PAM-13) } \\
\text { (Hibbard et al., } \\
\text { 2005) }\end{array}$ & $\begin{array}{l}\text { Severity of depressive } \\
\text { symptoms (Patient Health } \\
\text { Questionnarie-9 [PHQ-9]) } \\
\text { (Kroenke, Spitzer, \& } \\
\text { Williams, 2001) } \\
\text { Physical and mental } \\
\text { health status (12 Item } \\
\text { Short Term Survey [SF- } \\
\text { 12] Physical Component } \\
\text { Summary [PCS] and } \\
\text { Mental Component } \\
\text { Summary [MCS]) (Ware, } \\
\text { J. E., Kosinski, M., \& } \\
\text { Keller, 1996) } \\
\text { Exercise, activity } \\
\text { frequency, } \\
\text { smoking/alcohol intake, } \\
\text { Sociodemographic (age, } \\
\text { birthplace, preferred } \\
\text { language, health service } \\
\text { utilization, treatments) }\end{array}$ & 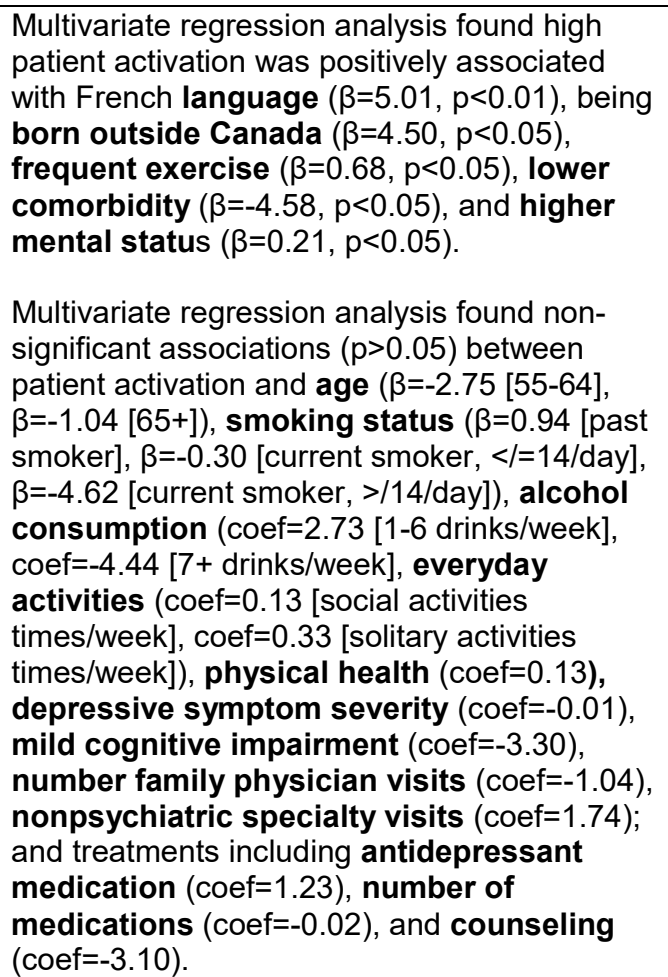 & $\mathrm{I}, \mathrm{A}$ \\
\hline $\begin{array}{l}\text { Oles et al. } \\
\text { (2015) }\end{array}$ & $\begin{array}{l}\text { Secondary } \\
\text { analysis from } \\
\text { randomized } \\
\text { control trial }\end{array}$ & $\begin{array}{l}\text { "To examine the } \\
\text { prospective } \\
\text { relationship } \\
\text { between hope } \\
\text { and patient } \\
\text { activation over } \\
\text { time" (p. 273) }\end{array}$ & $\begin{array}{l}\text { Patients with } \\
\text { schizophrenia } \\
\text { receiving } \\
\text { mental health } \\
(\mathrm{MH}) \text { services } \\
\text { at VA Medical } \\
\text { Center or } \\
\text { community MH } \\
\text { center in } \\
\text { Indiana } \\
(\mathrm{N}=118)\end{array}$ & $\begin{array}{l}\text { Patient activation } \\
\text { (PAM-MH) (Green } \\
\text { et al., 2010) }\end{array}$ & $\begin{array}{l}\text { Hope (AHS) (Snyder et al., } \\
\text { 1996) } \\
\text { Demographics (gender, } \\
\text { age, race, education) }\end{array}$ & $\begin{array}{l}\text { Cross lagged panel model showed positive } \\
\text { correlation between hope and patient } \\
\text { activation at baseline }(r=0.57, p<0.001), 9 \\
\text { months }(r=0.62, p<0.001), 18 \text { months }(r=0.67 \text {, } \\
p<0.001) \text {. } \\
\text { Correlation matrix showed non-significant } \\
\text { associations ( } p>0.01) \text { between patient } \\
\text { activation and gender (coef }=-0.09 \text { [ } 9 \text { months], } \\
\text { coef }=-0.06[18 \text { months], age (coef }=0.01 \text { [ } 9 \\
\text { months], coef }=-0.02[19 \text { months], race (coef }=- \\
0.13[9 \text { months], coef }=-0.16[18 \text { months], and } \\
\text { education }(\text { coef }=-0.08 \text { [ } 9 \text { months], coef }=0.03 \\
{[18 \text { months]). }}\end{array}$ & III, $A^{\text {TI }}$ \\
\hline $\begin{array}{l}\text { Pinto et } \\
\text { al. (2017) }\end{array}$ & $\begin{array}{l}\text { Correlational, } \\
\text { cross- } \\
\text { sectional }\end{array}$ & $\begin{array}{l}\text { "Explore the } \\
\text { predictive } \\
\text { relationships of }\end{array}$ & $\begin{array}{l}\text { People with } \\
\text { self-reported } \\
\text { depression in }\end{array}$ & $\begin{array}{l}\text { Patient activation } \\
\text { (PAM-13) }\end{array}$ & $\begin{array}{l}\text { Quality of interaction with } \\
\text { a provider (Quality of } \\
\text { Provider-Patient }\end{array}$ & $\begin{array}{l}\text { Path analysis revealed that the quality of } \\
\text { patient-provider communication }(\beta=.43, p \\
<.01) \text { and self-appraisal of communication }\end{array}$ & III, B \\
\hline
\end{tabular}




\begin{tabular}{|c|c|c|c|c|c|c|c|}
\hline & & $\begin{array}{l}\text { the clinical } \\
\text { encounter, } \\
\text { which includes } \\
\text { communication } \\
\text { functions and } \\
\text { proximal } \\
\text { outcomes to } \\
\text { improve health } \\
\text { outcomes" (p. } \\
533 \text { ) }\end{array}$ & $\begin{array}{l}\text { Northeast Ohio } \\
(\mathrm{N}=60)\end{array}$ & $\begin{array}{l}\text { (Hibbard et al., } \\
\text { 2005) }\end{array}$ & $\begin{array}{l}\text { Interaction [QQPPI]) } \\
\text { (Bieber, Muller, Nicolai, } \\
\text { Hartmann, \& Eich, 2010) } \\
\text { Self-appraisal of } \\
\text { communication skills with } \\
\text { providers (Patients' Self } \\
\text { Competence Subscale } \\
\text { [PSC]) (Cegala, Coleman, } \\
\text { \& Turner, 1998) } \\
\\
\text { Depressive symptom } \\
\text { levels (depressive } \\
\text { symptom subscale of the } \\
\text { Hospital Anxiety and } \\
\text { Depression Scale [HADS]) } \\
\text { (Zigmond \& Snaith, 1983) }\end{array}$ & $\begin{array}{l}\text { skills with providers }(\beta=.30, p<.05) \\
\text { (communication functions) had direct effects } \\
\text { on patient activation ( } R 2=.45, p<.01 \text { ) } \\
\text { (proximal outcome). } \\
\text { Patient activation was found to have direct } \\
\text { effects on depressive symptoms ( } \beta=-0.55 \text {, } \\
p<0.01 \text { ). }\end{array}$ & \\
\hline $\begin{array}{l}\text { Sacks et } \\
\text { al. (2014) }\end{array}$ & $\begin{array}{l}\text { Correlational, } \\
\text { cross } \\
\text { sectional }\end{array}$ & $\begin{array}{l}\text { "Explore the } \\
\text { relationship } \\
\text { between } \\
\text { baseline patient } \\
\text { activation in } \\
\text { depressed } \\
\text { patients and } \\
\text { depression } \\
\text { outcomes one } \\
\text { year later" (p.2) }\end{array}$ & $\begin{array}{l}\text { Patients with } \\
\text { moderate to } \\
\text { severe } \\
\text { depression } \\
\text { receiving care } \\
\text { at Fairview } \\
\text { Health } \\
\text { Services } \\
\text { Minnesota } \\
(\mathrm{N}=5253)\end{array}$ & $\begin{array}{l}\text { Patient activation } \\
\text { (PAM-13) } \\
\text { (Hibbard et al., } \\
\text { 2005) }\end{array}$ & $\begin{array}{l}\text { Depression (PHQ-9) } \\
\text { (Kroenke et al., 2001); } \\
\text { depression treatment } \\
\text { response, depression } \\
\text { remission, and depression } \\
\text { severity variables } \\
\text { Self-reported depression } \\
\text { recovery variables } \\
\text { (quitting smoking, lowering } \\
\text { BMl, newly meeting } \\
\text { clinical recommendations } \\
\text { for Papanicolaou (PAP) } \\
\text { smears, newly meeting } \\
\text { clinical recommendations } \\
\text { for mammography) }\end{array}$ & 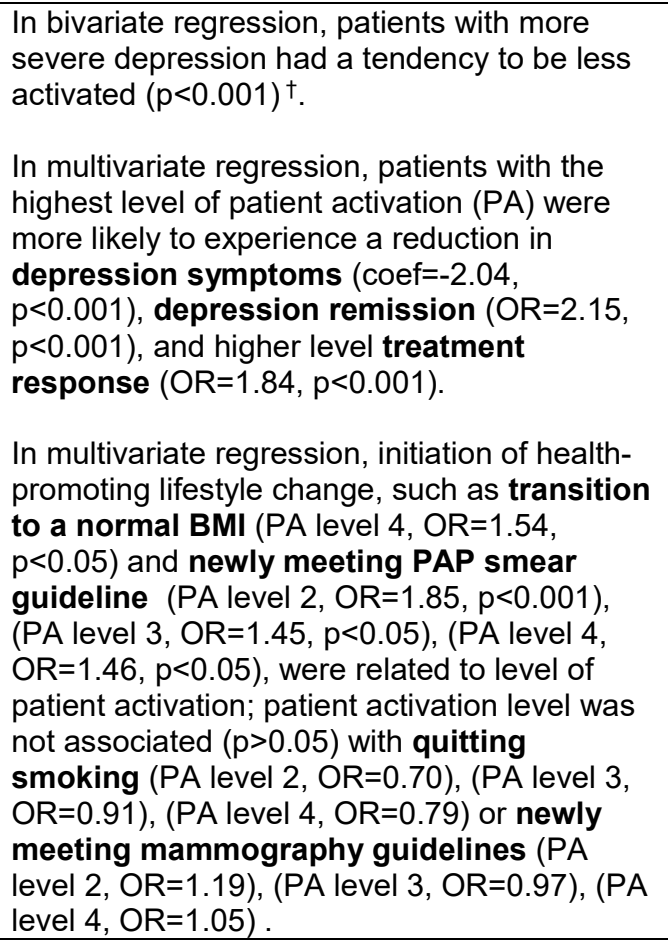 & III, A \\
\hline $\begin{array}{l}\text { Singla et } \\
\text { al. (2020) }\end{array}$ & $\begin{array}{l}\text { Secondary } \\
\text { data analysis } \\
\text { from two } \\
\text { parallel } \\
\text { controlled }\end{array}$ & $\begin{array}{l}\text { "Explore the } \\
\text { potentially } \\
\text { predictive and } \\
\text { mediating roles } \\
\text { of treatment and } \\
\text { patient }\end{array}$ & $\begin{array}{l}\text { Study } \\
\text { participants } \\
\text { from Health } \\
\text { Activity } \\
\text { Program [HAP] } \\
\text { and }\end{array}$ & $\begin{array}{l}\text { Patient activation } \\
\text { (PREMIUM } \\
\text { Abbreviated } \\
\text { Activation Scale } \\
\text { [PAAS] based on } \\
\text { Behavioral } \\
\end{array}$ & $\begin{array}{l}\text { Depression (depressive } \\
\text { symptoms severity scores } \\
\text { from the PHQ-9) (Kroenke } \\
\text { et al., 2001) }\end{array}$ & $\begin{array}{l}\text { In multiple linear regression, patient activation } \\
\text { was positively associated with therapy quality } \\
\text { treatment-specific }(r=0.303, p=0.034) \text { and } \\
\text { general skills ( } r=0.346, p=0.015) \text {; patient } \\
\text { activation was negatively associated with } \\
\text { depression }(r=-0.458, p=0.0008) \text {. }\end{array}$ & III, AT \\
\hline
\end{tabular}




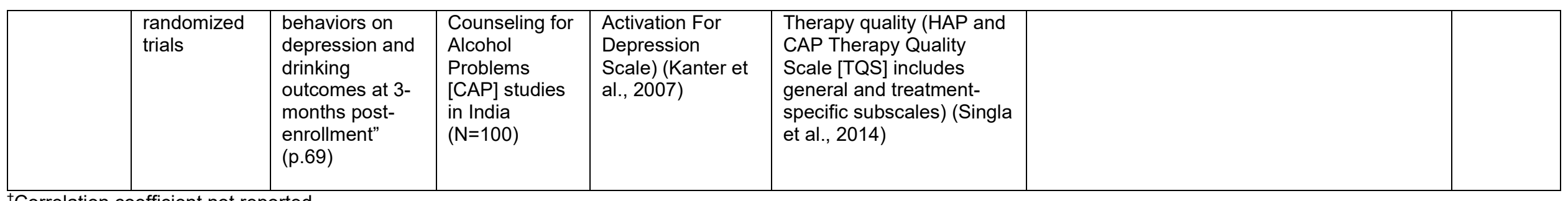

${ }^{\dagger}$ Correlation coefficient not reported.

§Data for correlational objectives reported from multivariate model (data for intervention objective reported in Table 2)

ॠAppraisal based on current sub study (not parent studies)

Table 2: Patient activation interventions

\begin{tabular}{|c|c|c|c|c|c|c|c|}
\hline Author (year) & Design & Purpose & Intervention & Sample/Setting & $\begin{array}{l}\text { Activation } \\
\text { Variable } \\
\text { (Measure) }\end{array}$ & Findings & $\begin{array}{l}\text { Evidence } \\
\text { Level, } \\
\text { Quality } \\
\end{array}$ \\
\hline \multicolumn{8}{|c|}{ Educational interventions } \\
\hline $\begin{array}{l}\text { Alegria et al. } \\
(2014)\end{array}$ & $\begin{array}{l}\text { Randomized } \\
\text { clinical trial } \\
\text { (mixed } \\
\text { efficacy- } \\
\text { effectiveness) }\end{array}$ & $\begin{array}{l}\text { "To determine whether } \\
\text { the DECIDE intervention } \\
\text { improves patient } \\
\text { activation and self- } \\
\text { management, as well as } \\
\text { engagement and } \\
\text { retention in behavioral } \\
\text { health care" (p. 557) }\end{array}$ & $\begin{array}{l}\text {-DECIDE is an educational program } \\
\text { to help patients ask questions and } \\
\text { make decisions with providers. } \\
-3 \text { in-person sessions over } 3 \\
\text { months ( } 30-45 \text { minutes per session) } \\
\text { led by bilingual care managers }\end{array}$ & $\begin{array}{l}\text { Patients from } 13 \\
\text { outpatient } \\
\text { community mental } \\
\text { health clinics in the } \\
\text { U.S. and Puerto } \\
\text { Rico; were } \\
\text { generally low- } \\
\text { income } \\
\text { Latino/other } \\
\text { minority }(\mathrm{N}=647)\end{array}$ & $\begin{array}{l}\text { Patient activation } \\
\text { (Patient } \\
\text { Activation Scale } \\
\text { [PAS]) (Alegría } \\
\text { et al., 2008) }\end{array}$ & $\begin{array}{l}\text { In mixed } \\
\text { regression } \\
\text { analysis, the } \\
\text { intervention group } \\
\text { had higher patient } \\
\text { activation }(\beta= \\
1.74[0.58] ; P= \\
.003) \text { compared to } \\
\text { control. }\end{array}$ & $\mathrm{I}, \mathrm{A}$ \\
\hline $\begin{array}{l}\text { Bartels et al. } \\
\text { (2013) }\end{array}$ & $\begin{array}{l}\text { Quasi- } \\
\text { experimental, } \\
\text { pre-post pilot }\end{array}$ & $\begin{array}{l}\text { "To pilot test study } \\
\text { feasibility and potential } \\
\text { effectiveness of a } \\
\text { collaborative activation } \\
\text { training in primary care } \\
\text { (CAT-PC)" program (p. } \\
278 ; 279)\end{array}$ & $\begin{array}{l}\text {-CAT-PC includes co-led patient } \\
\text { education and training and training } \\
\text { for primary care providers. } \\
-9 \text { weekly peer co-led patient } \\
\text { education and skills training session } \\
\text { ( } 90 \text { minutes per session) over } 2 \\
\text { months; interveners were PhD } \\
\text { social worker }+2 \text { wellness peer } \\
\text { specialists; } 45 \text { minute video-based } \\
\text { training for primary care providers }\end{array}$ & $\begin{array}{l}\text { Patients with a } \\
\text { serious mental } \\
\text { health illness and } \\
\text { cardiovascular } \\
\text { health risk } \\
\text { conditions from } 2 \\
\text { primary care } \\
\text { mental health } \\
\text { centers in New } \\
\text { Hampshire }(\mathrm{N}=17)\end{array}$ & $\begin{array}{l}\text { Patient activation } \\
\text { (PAM-13) } \\
\text { (Hibbard et al., } \\
\text { 2005) }\end{array}$ & $\begin{array}{l}\text { In t-test repeated } \\
\text { measure analysis, } \\
\text { improvement was } \\
\text { found for patient } \\
\text { activation } \\
(E S=0.54, p=0.03) \\
\text { post intervention. }\end{array}$ & II, B \\
\hline $\begin{array}{l}\text { Chiang et al. } \\
\text { (2019) }\end{array}$ & $\begin{array}{l}\text { Randomized } \\
\text { clinical trial }\end{array}$ & $\begin{array}{l}\text { To explore "the effect of } \\
\text { DECIDE-PA program } \\
\text { (Decide the problem; } \\
\text { Explore the questions; } \\
\text { Closed or open-end } \\
\text { questions; Identify the } \\
\text { who, why, or how of the } \\
\text { problems; Direct }\end{array}$ & $\begin{array}{l}\text {-DECIDE-PA is a training program } \\
\text { that supports patients to learn about } \\
\text { their illness and learn } \\
\text { communication skills to discuss } \\
\text { treatment options and communicate } \\
\text { needs with health care } \\
\text { professionals }\end{array}$ & $\begin{array}{l}13 \text { hospital-based } \\
\text { and community } \\
\text { outpatient } \\
\text { Massachusetts } \\
\text { mental health } \\
\text { clinics }(\mathrm{N}=312)\end{array}$ & $\begin{array}{l}\text { Patient activation } \\
\text { (modified version } \\
\text { of PAS) (Alegría } \\
\text { et al., 2008) }\end{array}$ & $\begin{array}{l}\text { In multilevel, } \\
\text { mixed-effects } \\
\text { models, patient } \\
\text { intervention and } \\
\text { dose of clinician } \\
\text { interventions had } \\
\text { no effect on }\end{array}$ & $\mathrm{I}, \mathrm{A}$ \\
\hline
\end{tabular}




\begin{tabular}{|c|c|c|c|c|c|c|c|}
\hline & & $\begin{array}{l}\text { questions to your health } \\
\text { care professional; Enjoy a } \\
\text { shored solution) on both } \\
\text { mental illness symptoms } \\
\text { and patient activation, as } \\
\text { well as the relationship } \\
\text { between symptoms and } \\
\text { activation, in a diverse } \\
\text { clinical sample" (p.697) }\end{array}$ & $\begin{array}{l}\text {-DECIDE-PC is an intervention that } \\
\text { incorporates coaching and } \\
\text { workshops to improve clinicians' } \\
\text { skills to facilitate shared decision } \\
\text { making. } \\
\text {-12-hour workshop delivered by } \\
\text { behavioral health and } \\
\text { communication experts to clinicians } \\
+ \text { up to } 6 \text { coaching calls; up to } 3 \\
\text { training sessions ( } 60 \text { minutes) } \\
\text { delivered to patients }\end{array}$ & & & $\begin{array}{l}\text { patient activation } \\
(\mathrm{t}=-0.06 ; \mathrm{p}=0.95)\end{array}$ & \\
\hline $\begin{array}{l}\text { Druss et al. } \\
(2010)\end{array}$ & $\begin{array}{l}\text { Pilot } \\
\text { randomized } \\
\text { control trial }\end{array}$ & $\begin{array}{l}\text { "To describe the } \\
\text { development of [Health } \\
\text { and Recovery Program] } \\
\text { to assess its feasibility } \\
\text { and potential to improve } \\
\text { self-management and } \\
\text { health outcome" (p. 265) }\end{array}$ & $\begin{array}{l}\text {-The Health and Recovery Program } \\
\text { is adapted from the Chronic } \\
\text { Disease Self-Management Program } \\
\text { (CDSMP) delivered by mental } \\
\text { health peers to mental health } \\
\text { consumers } \\
\text {-Up to } 6 \text { group sessions led by } \\
\text { mental health peer leaders }\end{array}$ & $\begin{array}{l}\text { Patients with a } \\
\text { severe mental } \\
\text { health illness and } \\
\text { one or more } \\
\text { chronic condition } \\
\text { from an urban } \\
\text { community mental } \\
\text { health center in the } \\
\text { Midwest }(\mathrm{N}=80)\end{array}$ & $\begin{array}{l}\text { Patient activation } \\
\text { (PAM-13) } \\
\text { (Hibbard et al., } \\
\text { 2005) }\end{array}$ & $\begin{array}{l}\text { In random } \\
\text { regression } \\
\text { analyses, the } \\
\text { intervention group } \\
\text { had a greater } \\
\text { increase in patient } \\
\text { activation } \\
(p=0.03) \ddagger . \\
\text { compared to the } \\
\text { control group } \\
(52.0+/-10.1 \\
\text { intervention vs. } \\
44.9+/-9.6 \\
\text { control, } p=0.01) .\end{array}$ & $\mathrm{I}, \mathrm{B}$ \\
\hline $\begin{array}{l}\text { Fujita et al. } \\
(2010)\end{array}$ & $\begin{array}{l}\text { Quasi- } \\
\text { experimental, } \\
\text { pre/post }\end{array}$ & $\begin{array}{l}\text { "To investigate the } \\
\text { feasibility and outcomes } \\
\text { of the illness } \\
\text { management and } \\
\text { recovery program in } \\
\text { Japan." } \\
\text { (p. } 1157 \text { ) }\end{array}$ & $\begin{array}{l}\text {-Intervention was an illness } \\
\text { management and recovery program } \\
\text { to help patients learn about their } \\
\text { illness and acquire self- } \\
\text { management skills } \\
-60-90 \text { minute session } 1-2 \text { times per } \\
\text { week ( } 9 \text { total modules) delivered by } \\
\text { research team (psychiatrist, nurse, } \\
2 \text { clinical psychologists, } \\
\text { occupational therapist, psychiatric } \\
\text { social worker) }\end{array}$ & $\begin{array}{l}\text { Patients with } \\
\text { schizophrenia from } \\
2 \text { outpatient } \\
\text { hospital facilities } \\
(\mathrm{N}=18)\end{array}$ & $\begin{array}{l}\text { Patient activation } \\
\text { (PAM-MH) } \\
\text { (Green et al., } \\
\text { 2010) }\end{array}$ & $\begin{array}{l}\text { In t-test analyses, } \\
\text { activation } \\
\text { improved post- } \\
\text { treatment }(\mathrm{t}=5.22 \\
\mathrm{p}<0.05)\end{array}$ & II, B \\
\hline $\begin{array}{l}\text { Goldberg et } \\
\text { al. (2013) }\end{array}$ & $\begin{array}{l}\text { Randomized } \\
\text { controlled trial }\end{array}$ & $\begin{array}{l}\text { "To examine the } \\
\text { effectiveness of a } \\
\text { modified version of .... } \\
\text { Living Well for individuals } \\
\text { with serious mental } \\
\text { illness" (p. 51) }\end{array}$ & $\begin{array}{l}\text {-Living Well is a modified version of } \\
\text { the CDSMP, a peer-facilitated } \\
\text { intervention that includes training in } \\
\text { disease self-management. } \\
-13 \text { weekly sessions ( } 60-75 \\
\text { minutes) co-led by mental health } \\
\text { peer, mental health professional, } \\
\text { and/or peer provider }\end{array}$ & $\begin{array}{l}\text { Patients with } \\
\text { serious mental } \\
\text { illness with at least } \\
\text { one chronic } \\
\text { condition from } 4 \\
\text { mental health } \\
\text { settings (outpatient } \\
\text { clinics, psychiatric } \\
\text { rehab) in Maryland } \\
(\mathrm{N}=63)\end{array}$ & $\begin{array}{l}\text { Patient activation } \\
\text { (PAM-13) } \\
\text { (Hibbard et al., } \\
\text { 2005) }\end{array}$ & $\begin{array}{l}\text { In mixed effects } \\
\text { models, the } \\
\text { intervention group } \\
\text { had significantly } \\
\text { greater } \\
\text { improvements in } \\
\text { activation level } \\
(E S=0.55, t=2.08 \text {; } \\
p=0.042) \text { post- } \\
\text { program, }\end{array}$ & $\mathrm{I}, \mathrm{A}$ \\
\hline
\end{tabular}




\begin{tabular}{|c|c|c|c|c|c|c|c|}
\hline & & & & & & $\begin{array}{l}\text { compared to } \\
\text { control group. } \\
\text { However, results } \\
\text { were not } \\
\text { sustained at two } \\
\text { month follow-up. }\end{array}$ & \\
\hline $\begin{array}{l}\text { Kaltman et } \\
\text { al. (2016) }\end{array}$ & $\begin{array}{l}\text { Quasi- } \\
\text { experimental, } \\
\text { pre-posttest } \\
\text { feasibility }\end{array}$ & $\begin{array}{l}\text { "To examine the } \\
\text { feasibility, acceptability, } \\
\text { and safety of the } \\
\text { intervention in anticipation } \\
\text { of ultimately conducting a } \\
\text { full-scale randomized } \\
\text { controlled trial of the } \\
\text { intervention" (p. 89) }\end{array}$ & $\begin{array}{l}\text {-The integrated self-management } \\
\text { intervention was developed with } \\
\text { patients, family members, and } \\
\text { providers and included motivational } \\
\text { interviewing and behavioral } \\
\text { activation techniques. } \\
-6 \text { weekly individual sessions ( } 45 \\
\text { minutes) }+2 \text { booster sessions led } \\
\text { by chronic care managers }\end{array}$ & $\begin{array}{l}\text { Latino immigrants } \\
\text { with uncontrolled } \\
\text { diabetes and } \\
\text { depression } \\
\text { receiving care at a } \\
\text { primary care clinic } \\
\text { in the U.S. }(\mathrm{N}=18)\end{array}$ & $\begin{array}{l}\text { Patient activation } \\
\text { (PAM-13) } \\
\text { (Hibbard et al., } \\
\text { 2005) }\end{array}$ & $\begin{array}{l}\text { In paired t-tests, } \\
\text { participants had a } \\
\text { significant } \\
\text { improvement } \\
\text { patient activation } \\
(\mathrm{t}=-5.59, \mathrm{P}< \\
.001)\end{array}$ & II, B \\
\hline $\begin{array}{l}\text { Lara-Cabrera } \\
\text { et al. (2016) }\end{array}$ & $\begin{array}{l}\text { Parallel group } \\
\text { randomized } \\
\text { controlled trial }\end{array}$ & $\begin{array}{l}\text { "To evaluate the effect of } \\
\text { a peer co-led intervention, } \\
\text { added to treatment as } \\
\text { usual, on patient } \\
\text { activation in out-patient } \\
\text { mental health care } \\
\text { settings. Secondary aims } \\
\text { were to assess the effects } \\
\text { on patient satisfaction, } \\
\text { well-being, mental health } \\
\text { symptomatology, } \\
\text { motivation, and treatment } \\
\text { participation in mental } \\
\text { health services" (p. 761) }\end{array}$ & $\begin{array}{l}\text {-The pre-treatment education } \\
\text { intervention was designed to } \\
\text { encourage patients to actively } \\
\text { participate and take a role in their } \\
\text { personal health, based on principles } \\
\text { of self-management, patient } \\
\text { involvement, and peer support } \\
-4 \text { hour group seminar led by } \\
\text { psychiatrist, clinical psychologist, } \\
\text { peer educators, social worker, } \\
\text { physiotherapist, therapist (nurse, } \\
\text { psychologist) }\end{array}$ & $\begin{array}{l}\text { Patients from } 2 \\
\text { outpatient mental } \\
\text { health centers in } \\
\text { Norway }(\mathrm{N}=52)\end{array}$ & $\begin{array}{l}\text { Patient activation } \\
\text { (Norwegian } \\
\text { PAM-13) (Inger } \\
\text { Elise O. Moljord } \\
\text { et al., 2015) }\end{array}$ & $\begin{array}{l}\text { In mixed linear } \\
\text { models, the } \\
\text { intervention group } \\
\text { experienced } \\
\text { higher patient } \\
\text { activation from } \\
\text { baseline to one } \\
\text { month }(95 \% \mathrm{Cl} \text { : } \\
1.71,12.2 ; \\
\mathrm{p}=0.01) \text { and four } \\
\text { month }(95 \% \mathrm{Cl} \text { : } \\
0.35,11.8 ; \\
\mathrm{p}=0.04) \text { follow up } \\
\text { compared to } \\
\text { control. }\end{array}$ & $\mathrm{I}, \mathrm{A}$ \\
\hline $\begin{array}{l}\text { Muralidharan } \\
\text { et al. (2019) }\end{array}$ & $\begin{array}{l}\text { Randomized } \\
\text { controlled trial }\end{array}$ & $\begin{array}{l}\text { "To conduct a large RCT } \\
\text { comparing Living Well, a } \\
12 \text {-session group } \\
\text { intervention co-led by a } \\
\text { peer (a veteran with co- } \\
\text { occurring mental and } \\
\text { physical health } \\
\text { conditions) and a nonpeer } \\
\text { facilitator, with } 12 \\
\text { sessions of a didactic } \\
\text { Medical Illness Education } \\
\text { and Support group led by } \\
\text { a nonpeer facilitator" (p. } \\
\text { 20) }\end{array}$ & $\begin{array}{l}\text {-Living Well intervention, based on } \\
\text { the CDSMP, provides education } \\
\text { and training in problem solving and } \\
\text { action planning to enhance } \\
\text { motivation and self-efficacy } \\
-12 \text { sessions ( } 75 \text { minutes) co-led by } \\
\text { peer and non-peers }\end{array}$ & $\begin{array}{l}\text { Patients with } \\
\text { serious mental } \\
\text { health illness } \\
\text { receiving outpatient } \\
\text { services at one of } \\
\text { three VA medical } \\
\text { centers in the Mid- } \\
\text { Atlantic region of } \\
\text { the U.S. }(\mathrm{N}=242)\end{array}$ & $\begin{array}{l}\text { Patient activation } \\
\text { (Patient } \\
\text { Activation } \\
\text { Measure-22 } \\
\text { [PAM-22]) } \\
\text { (Hibbard et al., } \\
\text { 2004) }\end{array}$ & $\begin{array}{l}\text { In linear mixed } \\
\text { effects models, } \\
\text { participants in the } \\
\text { living well } \\
\text { intervention } \\
\text { experienced } \\
\text { greater increases } \\
\text { in } \\
\text { patient activation } \\
\text { (t=2.08, } p=0.038) \\
\text { compared to } \\
\text { control group. }\end{array}$ & $\mathrm{I}, \mathrm{A}$ \\
\hline $\begin{array}{l}\text { Turner et al. } \\
(2015)\end{array}$ & $\begin{array}{l}\text { Quasi- } \\
\text { experimental, }\end{array}$ & $\begin{array}{l}\text { "To evaluate a co- } \\
\text { produced and co- }\end{array}$ & $\begin{array}{l}\text {-The Depression SMP was } \\
\text { designed to increase activation and }\end{array}$ & $\begin{array}{l}\text { Patients diagnosed } \\
\text { with depression in }\end{array}$ & $\begin{array}{l}\text { Patient activation } \\
\text { (PAM-13) }\end{array}$ & $\begin{array}{l}\text { In intention-to- } \\
\text { treat and protocol }\end{array}$ & $\mathrm{II}, \mathrm{A}$ \\
\hline
\end{tabular}




\begin{tabular}{|c|c|c|c|c|c|c|c|}
\hline & $\begin{array}{l}\text { longitudinal } \\
\text { pre-post }\end{array}$ & $\begin{array}{l}\text { delivered depression self- } \\
\text { management program } \\
\text { (SMP) on patient } \\
\text { activation, depression, } \\
\text { anxiety, health status, } \\
\text { quality of life and self- } \\
\text { management ability } \\
\text { outcomes of people living } \\
\text { with depression" (p. 245) }\end{array}$ & $\begin{array}{l}\text { self-efficacy and decrease learned } \\
\text { helplessness through self- } \\
\text { management training. } \\
-7 \text { weekly group-based sessions ( } 3 \\
\text { hours) co-led by psychologist and } \\
\text { peer }\end{array}$ & $\begin{array}{l}\text { mental health } \\
\text { centers in the } \\
\text { United Kingdom } \\
\text { (U.K.) }(\mathrm{N}=114)\end{array}$ & $\begin{array}{l}\text { (Hibbard et al., } \\
2005 \text { ) }\end{array}$ & $\begin{array}{l}\text { analyses, patient } \\
\text { activation } \\
\text { improved post- } \\
\text { intervention } \\
(\mathrm{d}=0.61 ; p \\
<0.001)\end{array}$ & \\
\hline $\begin{array}{l}\text { Weisner et } \\
\text { al. (2016) }\end{array}$ & $\begin{array}{l}\text { Quasi- } \\
\text { experimental } \\
\text { nonrandomized } \\
\text { controlled trial }\end{array}$ & $\begin{array}{l}\text { "To examine the effects of } \\
\text { an intervention aiming to } \\
\text { link patients receiving } \\
\text { addiction treatment with } \\
\text { health care" (p. 804) }\end{array}$ & $\begin{array}{l}\text {-LINKAGE intervention provided } \\
\text { education and skills building with } \\
\text { use of a patient portal and } \\
\text { collaborative communication with } \\
\text { healthcare providers. } \\
\text { - } 6 \text { group-based sessions ( } 45 \\
\text { minutes, } 2 \text { per week) led by clinical } \\
\text { psychologist }\end{array}$ & $\begin{array}{l}\text { Patients from a } \\
\text { San Francisco } \\
\text { outpatient addiction } \\
\text { treatment clinic } \\
(\mathrm{N}=503)\end{array}$ & $\begin{array}{l}\text { Patient activation } \\
\text { (PAM-13) } \\
\text { (Hibbard et al., } \\
\text { 2005) }\end{array}$ & $\begin{array}{l}\text { In linear } \\
\text { regression } \\
\text { analysis, patient } \\
\text { activation in both } \\
\text { intervention and } \\
\text { control groups } \\
\text { improved } \\
\text { (increase of } 3 \text { or } \\
\text { more points) but } \\
\text { there was no } \\
\text { difference } \\
\text { between groups } \\
\text { (OR=1.32, 95\% } \\
\text { Cl: } 0.91-1.91, \\
p=0.14) .\end{array}$ & II, A \\
\hline \multicolumn{8}{|c|}{ Case management/patient navigation interventions } \\
\hline $\begin{array}{l}\text { Cabassa et } \\
\text { al. (2018) }\end{array}$ & $\begin{array}{l}\text { Quasi- } \\
\text { experimental, } \\
\text { pilot pre-post }\end{array}$ & $\begin{array}{l}\text { "To examine the } \\
\text { acceptability and } \\
\text { feasibility of Delivering } \\
\text { Bridges to Better Health } \\
\text { and Wellness } \\
\text { (B2BHW).... to explore its } \\
\text { initial impact on patient } \\
\text { activation, self-efficacy, } \\
\text { patient-rated quality of } \\
\text { care, receipt of preventive } \\
\text { primary care services, } \\
\text { and quality of life" (p. 164) }\end{array}$ & $\begin{array}{l}\text {-B2BHW is a cultural adaptation for } \\
\text { Hispanics with SMI of the primary } \\
\text { care referral and evaluation } \\
\text { (PCARE) program, an intervention } \\
\text { where health care managers } \\
\text { coordinate, connect and coach } \\
\text { patients to facilitate primary care } \\
\text { visits } \\
\text {-Individual } 12 \text { monthly sessions (60 } \\
\text { minutes per session); intervener } \\
\text { social worker }\end{array}$ & $\begin{array}{l}\text { Hispanics with } \\
\text { serious mental } \\
\text { illness at risk for } \\
\text { cardiovascular } \\
\text { disease from an } \\
\text { outpatient mental } \\
\text { health clinic in New } \\
\text { York }(\mathrm{N}=34)\end{array}$ & $\begin{array}{l}\text { Patient activation } \\
\text { (PAM-13) } \\
\text { (Hibbard et al., } \\
\text { 2005) }\end{array}$ & $\begin{array}{l}\text { In linear mixed } \\
\text { models, } \\
\text { improvements } \\
\text { were seen at } 12 \\
\text { months for patient } \\
\text { activation } \\
(E S=0.56, \\
p</=0.001) \text {, } \\
\text { moderate effect } \\
\text { compared to } \\
\text { baseline. }\end{array}$ & II, A \\
\hline $\begin{array}{l}\text { Chinman et } \\
\text { al. (2013) }\end{array}$ & $\begin{array}{l}\text { Cluster } \\
\text { randomized } \\
\text { controlled trial }\end{array}$ & $\begin{array}{l}\text { "To incorporate peer } \\
\text { specialists (PSs) into } \\
\text { traditional VHA case } \\
\text { management teams and } \\
\text { test the impact of PSs on } \\
\text { greater a broad range of } \\
\text { recovery outcomes ... it } \\
\text { was hypothesized that the } \\
\text { involvement of PSs would } \\
\text { lead to greater gains-at }\end{array}$ & $\begin{array}{l}\text {-PS functioned as part of the case } \\
\text { management team while drawing } \\
\text { on personal lived experiences to } \\
\text { deliver a variety of functions such } \\
\text { as leading group, meeting with } \\
\text { veterans, developing recovery } \\
\text { plans, delivering medication, and } \\
\text { going with veterans to } \\
\text { appointments. }\end{array}$ & $\begin{array}{l}\text { VA psychiatric } \\
\text { inpatients in the } \\
\text { Southwest U.S. } \\
(\mathrm{N}=282)\end{array}$ & $\begin{array}{l}\text { Patient activation } \\
\text { (PAM-MH) } \\
\text { (Green et al., } \\
\text { 2010) }\end{array}$ & $\begin{array}{l}\text { In mixed effect } \\
\text { regression, patient } \\
\text { activation } \\
\text { improved more in } \\
\text { the peer specialist } \\
\text { group than in } \\
\text { usual care } \\
(z=2.00, d f=01 \\
p=0.05) \text { at one } \\
\text { year follow up. }\end{array}$ & $\mathrm{I}, \mathrm{A}$ \\
\hline
\end{tabular}




\begin{tabular}{|c|c|c|c|c|c|c|c|}
\hline & & $\begin{array}{l}\text { the individual patient } \\
\text { level-in recovery, quality } \\
\text { of life, patient activation, } \\
\text { and to a lesser extent, } \\
\text { symptoms." (p. 111) }\end{array}$ & $\begin{array}{l}\text {-PS training and supervision } \\
\text { involved } 30 \text { hours of recovery } \\
\text { training, basic counseling skills and } \\
\text { psychosocial rehabilitation }+2 \text { day } \\
\text { training in illness management and } \\
\text { recovery }+ \text { supervision by internal } \\
\text { and external supervisor weekly }\end{array}$ & & & & \\
\hline $\begin{array}{l}\text { Guo et al. } \\
\text { (2019) }\end{array}$ & $\begin{array}{l}\text { Randomized } \\
\text { pragmatic } \\
\text { clinical trial }\end{array}$ & $\begin{array}{l}\text { "To examine whether the } \\
\text { Wellness Incentive and } \\
\text { Navigation (WIN) } \\
\text { intervention can improve } \\
\text { health-related quality of } \\
\text { life (HRQOL) among } \\
\text { Medicaid enrollees with } \\
\text { co-occurring physical and } \\
\text { behavioral health } \\
\text { conditions." } \\
\text { (p. 1156) }\end{array}$ & $\begin{array}{l}\text {-The Wellness Incentive } \\
\text { Intervention (WIN) provided patients } \\
\text { with a personal navigator and a } \\
\text { flexible wellness account. } \\
\text {-Initial visit + monthly telephone call } \\
+ \text { quarterly in-person meeting for a } \\
\text { total of } 3 \text { years }\end{array}$ & $\begin{array}{l}\text { Medicaid enrollees } \\
\text { with co-occurring } \\
\text { physical and } \\
\text { behavioral health } \\
\text { concerns in Texas } \\
(\mathrm{N}=1259)\end{array}$ & $\begin{array}{l}\text { Patient activation } \\
\text { (PAM-13) } \\
\text { (Hibbard et al., } \\
\text { 2005) }\end{array}$ & $\begin{array}{l}\text { In generalized } \\
\text { linear mixed } \\
\text { models, both } \\
\text { intervention and } \\
\text { control groups } \\
\text { had an increase in } \\
\text { patient activation } \\
\text { across all study } \\
\text { years. The } \\
\text { intervention group } \\
\text { experienced } \\
\text { higher patient } \\
\text { activation ( } 67.2 \text { vs } \\
64.8 ; \mathrm{t}=-2.21 ; \mathrm{P} \\
=.027) \text { at year } 3 \\
\text { compared to } \\
\text { control group. }\end{array}$ & $\mathrm{I}, \mathrm{A}$ \\
\hline $\begin{array}{l}\text { Schuster et } \\
\text { al. (2018) }\end{array}$ & $\begin{array}{l}\text { Comparative } \\
\text { effectiveness, } \\
\text { cluster- } \\
\text { randomized } \\
\text { design }\end{array}$ & $\begin{array}{l}\text { "To assess the impact of } \\
\text { two behavioral health } \\
\text { home approaches, } \\
\text { Patient Self-Directed care } \\
\text { and Provider-Supported } \\
\text { care, on several patient- } \\
\text { centered outcomes, } \\
\text { including activation in } \\
\text { care, health status, and } \\
\text { engagement " (p. 249) }\end{array}$ & $\begin{array}{l}\text {-Behavioral health home } \\
\text { intervention involving partnering } \\
\text { with mental health providers to } \\
\text { focus on holistic health and foster a } \\
\text { wellness culture amongst staff. } \\
\text {-Self-directed group were given } \\
\text { access to web-based portal (could } \\
\text { access independently or with } \\
\text { wellness coach); patient autonomy } \\
\text { encouraged. } \\
\text {-Provider-supported group had a } \\
\text { staffed registered nurse available } \\
\text { for consultation to wellness coaches } \\
\text { and provided care coordination } \\
\text { services. }\end{array}$ & $\begin{array}{l}\text { Medicaid enrollees } \\
\text { with serious mental } \\
\text { health illness } \\
\text { receiving services } \\
\text { from a participating } \\
\text { provider in } \\
\text { Pennsylvania } \\
(\mathrm{N}=1229)\end{array}$ & $\begin{array}{l}\text { Patient activation } \\
\text { (PAM-22) } \\
\text { (Hibbard et al., } \\
\text { 2004) }\end{array}$ & $\begin{array}{l}\text { In multivariate } \\
\text { analysis, patients } \\
\text { in the provider- } \\
\text { supported group } \\
\text { had a more rapid } \\
\text { increase in patient } \\
\text { activation } \\
\text { compared to self- } \\
\text { directed } \\
\text { behavioral health } \\
\text { homes as } \\
\text { evidenced by a } \\
\text { treatment by time } \\
\text { interaction } \mathrm{f} \\
(4,3164)=6.70, \\
\mathrm{p}<0.0001) .\end{array}$ & $\mathrm{I}, \mathrm{A}$ \\
\hline \multicolumn{8}{|c|}{ Web-based portal interventions } \\
\hline $\begin{array}{l}\text { Denneson et } \\
\text { al. (2019) }\end{array}$ & $\begin{array}{l}\text { Quasi- } \\
\text { experimental, } \\
\text { switching } \\
\text { replications }\end{array}$ & $\begin{array}{l}\text { "To evaluate whether the } \\
\text { web-based educational } \\
\text { program improved } \\
\text { patient-clinician } \\
\text { communication and }\end{array}$ & $\begin{array}{l}\text { A web-based educational program } \\
\text { in which patients read their mental } \\
\text { health notes online. }\end{array}$ & $\begin{array}{l}\text { Patients engaged } \\
\text { in mental health } \\
\text { treatment at the } \\
\text { VHA medical } \\
\text { center in the Pacific }\end{array}$ & $\begin{array}{l}\text { Patient activation } \\
\text { (PAM-MH) } \\
\text { (Green et al., } \\
\text { 2010) }\end{array}$ & $\begin{array}{l}\text { In fully adjusted } \\
\text { mixed models, } \\
\text { patient activation } \\
\text { scores in } \\
\text { healthcare }\end{array}$ & II, A \\
\hline
\end{tabular}




\begin{tabular}{|c|c|c|c|c|c|c|c|}
\hline & $\begin{array}{l}\text { design, } \\
\text { pre/post }\end{array}$ & $\begin{array}{l}\text { increased patient } \\
\text { activation" (p.4) }\end{array}$ & & $\begin{array}{l}\text { Northwest U.S. } \\
(\mathrm{N}=247)\end{array}$ & & $\begin{array}{l}\text { interactions } \\
\text { increased } \\
\text { significantly } \\
\text { between the pre } \\
\text { and post training } \\
\text { assessments } \\
\text { (PAM: pre-post } \\
\text { score change } \\
\mathrm{b}=2.71[1.41, \\
4.00], \mathrm{p}<0.01) . \\
\end{array}$ & \\
\hline $\begin{array}{l}\text { Kipping et al. } \\
(2016)\end{array}$ & $\begin{array}{l}\text { Quasi- } \\
\text { experimental, } \\
\text { observational } \\
\text { cohort }\end{array}$ & $\begin{array}{l}\text { "To conduct a benefits } \\
\text { evaluation of a patient } \\
\text { portal for patients } \\
\text { undergoing treatment for } \\
\text { serious or persistent } \\
\text { mental illness" (p. 2) }\end{array}$ & $\begin{array}{l}\text { Intervention was a web-based } \\
\text { portal that obtains health } \\
\text { information from the electronic } \\
\text { medical record }\end{array}$ & $\begin{array}{l}\text { Web-based portal } \\
\text { users undergoing } \\
\text { treatment for } \\
\text { serious or } \\
\text { persistent mental } \\
\text { illness in a tertiary } \\
\text { (inpatient or } \\
\text { outpatient) mental } \\
\text { health facility in } \\
\text { Canada }(\mathrm{N}=91) \\
\end{array}$ & $\begin{array}{l}\text { Patient activation } \\
\text { (Mental Health } \\
\text { Recovery } \\
\text { Measure } \\
\text { [MHRM] used as } \\
\text { a proxy for } \\
\text { activation) } \\
\text { (Bullock, 2005, } \\
\text { p. 36-40) }\end{array}$ & $\begin{array}{l}\text { In t-test analyses, } \\
\text { activation } \\
\text { increased post- } \\
\text { intervention } \\
(\mathrm{t}=-2.636, \mathrm{df}=130, \\
\mathrm{p}=0.01)\end{array}$ & II, A \\
\hline \multicolumn{8}{|c|}{ Other interventions } \\
\hline $\begin{array}{l}\text { McCusker et } \\
\text { al. (2016) }\end{array}$ & $\begin{array}{l}\text { Randomized } \\
\text { Pragmatic } \\
\text { Clinical Trial }\end{array}$ & $\begin{array}{l}\text { "To (1) describe the } \\
\text { cross-sectional } \\
\text { associations of activation } \\
\text { and self-efficacy with } \\
\text { demographics, physical } \\
\text { and mental health status, } \\
\text { health behaviors, } \\
\text { depression self-care, and } \\
\text { health care utilization; (2) } \\
\text { describe the longitudinal } \\
\text { associations of changes } \\
\text { over time in activation and } \\
\text { self-efficacy with changes } \\
\text { in health behaviors and } \\
\text { use of the Toolkit; and (3) } \\
\text { determine whether the } \\
\text { coaching intervention } \\
\text { increased activation } \\
\text { and/or self-efficacy at } \\
\text { follow up" (p. } 717 \text { ) }\end{array}$ & $\begin{array}{l}\text {-Intervention involved access to a } \\
\text { toolkit (informational DVD, mood } \\
\text { monitoring tool, antidepression } \\
\text { skills workbook) and assignment to } \\
\text { a lay coach. } \\
\text {-Assigned lay coach } \\
\text { (trained/supervised by clinical } \\
\text { psychologist); weekly calls (10 } \\
\text { minutes) offered for up to } 3 \text { months } \\
+6 \text { monthly calls }\end{array}$ & $\begin{array}{l}\text { Patients with at } \\
\text { least one chronic } \\
\text { condition and a } \\
\text { minimum of mild } \\
\text { depression } \\
\text { recruited from } 41 \\
\text { family doctors in } \\
\text { Canada }(N=215)\end{array}$ & $\begin{array}{l}\text { Patient activation } \\
\text { (PAM-13) } \\
\text { (Hibbard et al., } \\
\text { 2005) }\end{array}$ & $\begin{array}{l}\text { In linear } \\
\text { regression } \\
\text { analyses adjusting } \\
\text { for depression, } \\
\text { education, } \\
\text { counseling, } \\
\text { antidepressants, } \\
\text { and other } \\
\text { psychotropics, } \\
\text { both coached and } \\
\text { noncoached } \\
\text { groups } \\
\text { experienced an } \\
\text { increase in } \\
\text { activation at } 6- \\
\text { months compared } \\
\text { to baseline, with } \\
\text { no difference } \\
\text { between groups } \\
\text { (ES=0.14, 95\% } \\
\text { Cl: -0.11, 0.42; } \\
\text { p=0.324). }\end{array}$ & $\mathrm{I}, \mathrm{A}$ \\
\hline $\begin{array}{l}\text { Moljord et al. } \\
(2017)\end{array}$ & $\begin{array}{l}\text { Parallel-group } \\
\text { randomized } \\
\text { controlled trial }\end{array}$ & $\begin{array}{l}\text { "To assess the effect of a } \\
\text { self-referral to inpatient } \\
\text { treatment (SRIT) contract } \\
\text { on the primary outcome } \\
\text { patient activation (PAM- }\end{array}$ & $\begin{array}{l}\text {-The SRIT intervention was } \\
\text { designed to improve patient } \\
\text { participation and access to } \\
\text { treatment. }\end{array}$ & $\begin{array}{l}\text { Patients from a } \\
\text { community mental } \\
\text { health center in } \\
\text { central Norway } \\
(\mathrm{N}=53)\end{array}$ & $\begin{array}{l}\text { Patient activation } \\
\text { (Norwegian } \\
\text { PAM-13) (Inger } \\
\text { Elise O. Moljord } \\
\text { et al., 2015) }\end{array}$ & $\begin{array}{l}\text { In a linear mixed } \\
\text { model, there was } \\
\text { no significant } \\
\text { effect of SRIT on } \\
\text { patient activation }\end{array}$ & $\mathrm{I}, \mathrm{A}$ \\
\hline
\end{tabular}




\begin{tabular}{|c|c|c|c|c|c|c|c|}
\hline & & $\begin{array}{l}\text { 13). The secondary } \\
\text { outcomes were recovery } \\
\text { (RAS) and behavior and } \\
\text { symptoms identification } \\
\text { (BASIS-32) after } 12 \\
\text { months compared to } \\
\text { those who received } \\
\text { treatment as usual (TAU)" } \\
\text { (p. 1145) }\end{array}$ & $\begin{array}{l}\text {-After referral, patients received } \\
\text { consultation with psychiatric nurse. }\end{array}$ & & & $\begin{array}{l}(95 \% \mathrm{Cl}: 7.49, \\
6.67 ; p=0.91) \\
\text { compared to TAU. } \\
\text { In post hoc linear } \\
\text { regression, SRIT } \\
\text { had a significant } \\
\text { effect on patient } \\
\text { activation for } \\
\text { patients with a } \\
\text { PAM score below } \\
47(95 \% \mathrm{Cl}: 0.03 \text {, } \\
39.04 ; p=0.049)\end{array}$ & \\
\hline $\begin{array}{l}\text { Rise et al. } \\
(2016)\end{array}$ & $\begin{array}{l}\text { Parallel-group } \\
\text { randomized } \\
\text { controlled trial }\end{array}$ & $\begin{array}{l}\text { "To investigate the effect } \\
\text { on mental health and } \\
\text { patient activation after } 6 \\
\text { and } 12 \text { months from using } \\
\text { the PCOMS (partners for } \\
\text { change outcome } \\
\text { management system)" (p. } \\
\text { 164) }\end{array}$ & $\begin{array}{l}\text {-The intervention involved } \\
\text { implementation of a PCOMS } \\
\text { feedback system, creating } \\
\text { opportunity to collect and use } \\
\text { patient feedback on treatment } \\
\text { sessions }\end{array}$ & $\begin{array}{l}\text { Patients from a } \\
\text { Norway outpatient } \\
\text { unit within a mental } \\
\text { health hospital } \\
(\mathrm{N}=75)\end{array}$ & $\begin{array}{l}\text { Patient activation } \\
\text { (PAM-22) } \\
\text { (Hibbard et al., } \\
\text { 2004) }\end{array}$ & $\begin{array}{l}\text { In analysis of } \\
\text { covariance, there } \\
\text { were no } \\
\text { differences in } \\
\text { activation } \\
\text { between the } \\
\text { intervention and } \\
\text { control group at } 6 \\
\text { months (est. } \\
\text { diff=3.2; } 95 \% \mathrm{Cl} \text { : - } \\
8.7,2.3 ; \mathrm{p}=0.25) \\
\text { and } 12 \text { months } \\
\text { (est. diff=4.9; } 95 \% \\
\mathrm{Cl}:-0.7,10.5 ; \\
\mathrm{p}=0.082) .\end{array}$ & $\mathrm{I}, \mathrm{B}$ \\
\hline
\end{tabular}

¥Comparison index not reported. 